\title{
Konstruksi Realitas Sosial Terhadap Kenaikan Harga Bahan Bakar Minyak (Kajian Semiotik Terhadap Lirik Lagu "Kritis BBM" Karya Slank)
}

\author{
Barkah Hadamean Harahap \\ Institut Agama Islam Negeri Padangsidempuan, Kota Padang Sidempuan, Indonesia \\ Jl. T. Rizal Nurdin Km. 4,5 Sihitang Kota Padangsidempuan \\ Koresponden: barkahhrp@gmail.com
}

\begin{abstract}
ABSTRAK
Permasalahan penelitian ini adalah lirik lagu Kritis BBM yang dijadikan sebagai pesan komunikasi yang mengarah pada konstruksi realitas sosial kenaikan harga bahan bakar minyak (BBM). Fokus permasalahan penelitian ini adalah denotasi dan konotasi perspektif Barthes dalam lirik lagu Kritis BBM dampak sosial kenaikan harga bahan bakar minyak (BBM). Metode penelitian yang digunakan dengan pendekatan kualitatif-deskriptif. Berdasarkan temuan penelitian ini menunjukkan denotatif dan konotatif konstruksi realitas sosial dampak kenaikan harga BBM. Bentuk dari konstruksi realitas sosial yang ditemukan adalah menggambarkan pesan konstruktif tentang regenerasi masa depan, masa depan pendidikan dan kesehatan, kurangnya kesejahteraan pada rakyat miskin, hegemoni sosial, kritik konsep hidup sederhana, kebijakan pemerintah tidak transparan, guncangan stabilitas sosial dan kecurangan alokasi bantuan dana kompensasi. Adanya bentuk realitas sosial tersebut menunjukkan bahwa lirik lagu tersebut bertujuan mengubah pendapat, mempengaruh dan ajakan mengubah sikap dan perilaku audiens.
\end{abstract}

Kata Kunci: Konstruksi, Realitas Sosial dan Bahan Bakar Minyak

\begin{abstract}
Problems of research is a Kritis BBM lyrics' serve as the communication messages which lead to the construction of social reality of rising fuel prices. The focus of this research is denoted problems and connotations of Barthes's perspective in the lyrics of critical social impact of feuel price increases of fuel oil. The research method used was qualitative-descriptive approach.Based on the findings of this study showed in denotative and connotative construction of the social reality of the impact of the rising prices of fuel oil in the lyrics of a Kritis BBM proved based on the use of nonformal language, terminology, punctuation and the story in the lyrics. The form of the construction of social reality that is found is the constructive message describing about the regeneration of the future, the future of education and health, lack of well-being on the poor, the hegemony of social criticism, the concept of simple living, government policies are not transparent, social instability, and aid allocation fund compensation fraud. The existence of the social form of reality shows that the song's lyrics aim to change opinions, under the solicitation and change the attitude and behavior of audiencess.
\end{abstract}

Keywords: Construction, Social Reality, Fuel

\section{Pendahuluan}

Musik adalah sesuatu yang tidak bisa lepas dari kehidupan manusia. Musik adalah ilmu atau seni menyusun nada atau suara diutarakan, kombinasi dan hubungan temporal untuk menghasilkan komposisi suara yang mempunyai keseimbangan dan kesatuan nada atau suara yang disusun sedemikian rupa sehingga mengandung irama, lagu dan keharmonisan terutama yang dapat menghasilkan bunyi. (Tim Penyusun Pusat Bahasa, 2008:602) Kepopuleran musik menjadi salah satu gaya hidup masa kini. Dewasa ini musik telah familiar di berbagai kalangan sosial. Kebanyakan orang menganggap bahwa musik adalah kebutuhan batin yang sekunder. Banyak orang mendengarkan musik dalam perjalanan, di rumah, pagi hari, dan di berbagai tempat tertentu merupakan hal yang wajar. Adanya kebutuhan manusia terhadap musik memberikan nilai ekonomis entertainer bagi 
para musisi. Hal ini dibuktikan dengan muncul berbagai genre musik seperti rock, pop, jazz, blues, dan lain sebagainya.

Selain itu, musik mudah dinikmati melalui media televisi, radio, membeli di toko musik, dan internet yang memberikan pilihan sesuai selera dan kebutuhan. Pilihan itu mendorong kesejahteraan ekonomi industri musik. Saat ini, nilai penting musik popular yang tentu saja bersifat kultural dan ekonomi, telah membawa kepada fokus dalam kultural studies (Storey, 1996:14). Musik menjadi salah satu unsur dalam kehidupan yang sangat penting sifatnya. Karena itu fungsi musik dalam kehidupan adalah sebagai hiburan.

Musik tidak hanya sekadar lagu-lagu yang didendangkan dengan alunan irama dan petikan gitar ataupun pukulan gendang. Tetapi jauh dari makna yang ada di dalam lagu, terdapat suatu makna tersembunyi pada lirik yang didendangkan para musisi. Hal inilah maksud yang diuraikan oleh D. Taylor bahwa "kata-kata adalah bunyi yang bisa kita rasakan terlebih dahulu sebelum menjadi pernyataan-penyataan yang dapat dipahami" (Simon dan Goodwin (ed), 1983:14) Kehadiran musik dalam berbagai kesempatan dapat mengisi waktu senggang dan waktu kerja sebagai media komunikasi yang tak perlu diragukan lagi. Musik di kalangan anak muda, menjadi media hiburan dalam ruang publik dan privasi yang menjadi bagian tak terpisahkan dari budaya etnik, ritual tersendiri serta menjadi identitas yang khas.

Lirik lagu dapat menjadi medium pernyataan sosial yang sangat asas dalam kehidupan manusia. Di Indonesia musisi dan band yang sering menyinggung para pejabat pemerintahan melalui lirik-lirik lagunya dengan kritis tajam salah satunya adalah Band Slank. Pada dasarnya Band Slank memiliki idealisme yang tinggi dalam menciptakan karya-karyanya. Slank selalu membawakan berbagai macam tema menarik dalam setiap lagu yang dibawakan. Hal ini membuat Slank tampil sedikit berbeda dengan penyanyi atau grup musik yang telah ada pada saat itu yang lebih dominan membawakan lagu-lagu bertemakan cinta. Beberapa tema dalam lagu-lagu Slank dari kelima album tersebut antara lain percintaan, alam, kritik sosial, gaya hidup remaja, dan tema-tema lagu ekspresif.

Di penghujung tahun 2005, Slank kembali merilis sebuah album studio ke 14 nya yang diberi titel SLANKISSME. Ulang tahun Slank yang ke-22 tahun di Ancol pun sedikit banyak telah memainkan lagu-lagu baru dari album tersebut. Konser ulang tahun yang kali ini pun dimeriahkan oleh PAS Band, Peterpan, Naif, Seurieus, J-Rock's, The Brandals, Speaker F1rst, Teamlo, Melanie Soebono, Ratu, Cokelat, Jacko, Shanty dan lain-lain (www.slank.com, 2014). Di beberapa lagu, Slank berkolaborasi dengan para bintang tamu. Konon, total lagu yang dimainkan Slank sepanjang konser tersebut adalah 40 lagu. Album Slankissme sendiri adalah sebuah ambigu kalimat dari Slank Kiss Me, Slank Is Me, dan Slankisme. Bimbim menyebut bahwa ada "13 ajaran 'gak sempurna" dari Slankisme di antaranya adalah:

1. Kita harus "Kritis"

2. Berjiwa "Sosial"

3. Penuh "Solidaritas"

4. Saling "Setia"

5. Selalu "Merdeka"

6. Hidup "Sederhana"

7. Mencintai "Alam"

8. "Manusiawi"

9. Berani untuk "Beda"

10. Menjunjung "Persahabatan" 


\section{Punya "Angan" yang tinggi \\ 12. Menjadi "Diri" sendiri \\ 13. Membuka "Otak" dan "Hati" kita}

Idealisme ini harus diketahui oleh para Slanker agar mengerti dan menjalaninya. Kenapa, karena memang kesempurnaan hanya milik Tuhan. Begitu kata Bimbim. "Tiga belas ajaran gak sempurna ini" dijadikan manifesto Slank, dan Bimbim selalu membacakannya di saat Slank berkunjung ke suatu negara. Namun, Di dalam negeri pun Slank sering kali membacakan manifesto-nya tersebut. (www.slank.com, 2014).

Lagu Kritis BBM adalah salah satu lagu dari album Slankisme yang menghadirkan 13 lagu terbaru Slank yang belum pernah edar dengan warna musik yang semakin beragam dan kedewasaan pada lirik dengan lebih menyoroti masalah sosial masyarakat. Album yang diedarkan dalam bentuk kaset dan compact disc ini diisi oleh Kaka (vokal), Abdee (Guitars), Ridho (Guitars), Ivanka (Basses) dan Bimbim (Drums) dengan Slank Records sebagai executive producer, Slank sebagai produser, dan Program/ PT. Virgo Ramayana Record sebagai distributor. Untuk proses recording album ini dilakukan di Parah StudioPotlot dengan tracking \& mixing oleh Ozone dan mastering-nya dikerjakan oleh Donni TNL ( Don I Bart ) di Big Knob Studio.

Ide cover album ini lahir dari Bimbim \& Kaka yang kemudian digarap oleh Refiq Prasetyo dengan kehadiran beragam ilustrasi buatan Khobes Tattoo, dan foto-foto Slank oleh Indira Saraswati. Bonus pembelian album yang disponsori oleh PT. Gudang Garam Tbk. ini adalah sebuah gantungan handphone dan hits single-nya adalah lagu SBY (Sosial Betawi Yoi), Yang Manis, dan Gak Ada 2 Nya (www.slank.com, 2014).

Para ilmuwan komunikasi politik seperti Street, (1986) Cloonan dan Street, (1997) serta Van Zoonen, (2005) mulai mengkaji secara mendalam cara-cara budaya popular berfungsi dalam politik. Kebanyakan perhatian dicurahkan pada musik dan khususnya pada masa kampanye politik calon legislatif daerah maupun pusat. Kebanyakan mereka menghadirkan musisi sebagai stimulus untuk menarik perhatian massa. Hal di atas sejalan dengan pendapat Mark Mattern (1998) kontribusi musik bagi aksi kolektif melalui cara musik menjadi suatu bentuk komunikasi yang memungkinkan kelompok membangun makna dan kepentingan kolektif. (Mattern, 1998: 28-29)

Bagaimana dengan Band Slank. Sejak tahun 1983 banyak album musik karya band ini dengan sederetan musik yang booming dengan tema-tema sosial. Hingga sekarang Slank masih aktif berkarya di bidang seni tarik suara dan masih terus berkembang.

Berbagai lirik lagu yang dinyanyikan Slank ada sebuah lagu yang berjudul Kritis $B B M$. Meskipun lagu ini dirilis tahun 2005 namun muatan lirik lagu ini tetap kontekstual di zaman ini, karena menyingung realitas dari bahan bakar minyak yang harganya melambung tinggi. Lagu inilah salah satu karya Slank yang masih populer dengan realitas kenaikan harga. Peneliti dalam melihat lirik lagu ini sebagai sebuah tanda masih bersifat kontekstual dengan realitas sosial di zaman ini, terutama masalah kenaikan harga yang banyak mempengaruhi kesejahteraan dan ekonomi rakyat miskin.

Tampak nyata dalam lirik lagu Slank bahwa mereka membiarkan kebebasan berekspresinya, karena apa yang mereka tuangkan dalam lirik lagu adalah pemberontakan terhadap realitas keseharian yang mereka alami. Suatu penolakan terhadap realitas yang ada, yang pada akhirnya ia tuangkan dalam 'bahasa' Slank, bahasa yang sederhana dan apa adanya. Unsur teks bahasa dalam lirik lagu memang menjadi unsur yang paling utama. Berkaitan dengan ilmu komunikasi bahwa proses komunikasi secara primer adalah proses penyampaian pikiran dan perasaan seseorang kepada orang lain dengan menggunakan 
lambang (symbol) sebagai media. Lambang sebagai media primer dalam proses komunikasi adalah bahasa, isyarat, gambar, warna dan lain sebagainya yang secara langsung mampu 'menerjemahkan' pikiran atau perasaan komunikator kepada komunikan. Bahwa bahasa yang paling banyak digunakan dalam komunikasi adalah jelas karena hanya bahasalah yang mampu 'menerjemahkan' pikiran seseorang kepada orang lain. Apakah itu berbentuk ide, informasi atau opini, baik mengenai hal yang begitu konkrit maupun yang abstrak. (Effendy, 1994:11)

Keberanian Slank dan rekan-rekan musisi lainnya dalam melakukan kritik bukannya tanpa rintangan, khususnya ketika berhadapan dengan penguasa. Susetiawan (1997: 4) mengatakan bahwa ketika kritik dilakukan dengan arti harfiah tanpa mengingat budaya yang sedang berlangsung seperti di Indonesia di zaman orde baru, pelakunya bisa mendapat imbalan yang tidak menguntungkan sebab mengkritik bisa dianggap memusuhi.

Beranjak dari latar belakang permasalahan yang disebutkan di atas peneliti tertarik untuk mengkonstruksi realitas sosial dari dampak kenaikan harga BBM. Berdasarkan hal ini peneliti memfokuskan konstruksi pada realitas sosial kenaikan harga BBM dalam lirik lagu Kritis BBM karya Slank. Lirik lagu Kritis BBM dijadikan sebagai pesan komunikasi yang mengarah pada konstruksi realitas sosial. Sub fokus permasalahan penelitian ini adalah denotasi dan konotasi lirik lagu Kritis BBM dalam mengkonstruksikan realitas sosial kenaikan harga. Peneliti cenderung memilih rumusan permasalahan secara proporsional. Oleh karena itu rumusan permasalahan dalam penelitian ini adalah bagaimana konstruksi realitas sosial kenaikan harga Bahan Bakar Minyak (BBM) dalam lirik lagu Kritis BBM Karya Slank perspektif semiotika komunikasi Barthes? Adapun maksud penelitian ini adalah untuk melihat konstruksi realitas sosial berdasarkan lirik lagu "Kritis BBM" karya Slank. Hal ini karena lirik-lirik lagu yang dihasilkan Slank relevan dengan realitas sosial kenaikan harga BBM di Indonesia hingga saat ini.

Penelitian ini berawal dari latar belakang masalah asumsi bahwa musik lebih sekadar sebagai hiburan dan untuk kepentingan meraup keuntungan ekonomi semata. Banyaknya musik populer yang muncul di Indonesia, peneliti melihat band Slank termasuk sebagai band yang tidak hanya mementingkan nilai-nilai ekonomi, namun juga mengutamakan hasil ciptaannya, yaitu musik dan lagu kritik sosial di Indonesia. Oleh karena itu, musik dan lagu tersebut dibangun dalam sebuah realitas sosial yang riil di masyarakat. Permasalahannya musik dan lirik lagu dari band Slank yang popularitasnya diakui di kancah musik Indonesia.

Penelitian akan menggunakan metode deskriptif dan analisis wacana dengan pendekatan linguistik terhadap lirik-lirik lagu karya slank. Lagu-lagu yang dianalisis Nurahim pada unit analisisnya sebagai berikut:

1. Album Suit-Suit He..He (1991),

2. Album Piss,

3. Album Generasi Biru; Biru, Serba Salah, Hey Bung, Feodalisme dan Birokrasi Complek,

4. Album Minoritas; Pak Tani, Ham Burger, Tut Wuri Handayani dan Suku Benalu,

5. Album Mata Hati Reformasi dalam album ini lagu Nagih Janji, Naik-Naik ke Puncak Gunung dan Aktor Intelektual

6. Album 999+09 (1999); Ngangkang, Orkes Sakit Hati.

7. Album PLUR (2004); Gosip Jalanan, Indonesia Una dan Atjeh Investigation

8. Album Slankissme (2006); Kritis BBM, Solidaritas dan Almai. 
Perpektif peneliti melihat lagu-lagu tersebut adalah dengan menempatkan musik dan lirik lagu Slank sebagai sistem ide perlawanan yang erat dengan teori kritis. Metode deskriptif sendiri digunakan untuk menerangkan perjalanan musik Slank dalam peta musik Indonesia serta berbagai faktor yang mempengaruhinya, termasuk faktor sosial. Sedangkan analisis wacana guna menangkap makna tematis dan retoris yang terdapat dalam lirik lagu Slank, serta menangkap makna realitas sosial dalam konteks sosial politik Indonesia. Darinya diharapkan dapat ditangkap tentang musik dan lirik lagu Slank sebagai satu bentuk seni yang bukan sebagai hiburan semata namun juga sebagai refleksi atas realitas sosial di Indonesia.

Hasil kajian menunjukkan bahwa musik dan lirik lagu Slank dalam penciptaannya selalu dipengaruhi oleh beberapa faktor eksternal dan internal. Faktor eksternal sendiri meliputi; pengaruh globalisasi musik, pengaruh musikal, pengaruh ekonomis dan pengaruh sosial politik. Sedangkan faktor internal adalah pengalaman Slank dan pribadi personel Slank. Selain itu, musik dan lirik lagu kritik sosial Slank setidaknya memiliki fungsi di masyarakat. Fungsi tersebut selain sebagai fungsi hiburan, estetik, ekspresi emosional, dan fungsi komunikasi, juga memiliki kemungkinan fungsi utama, yaitu fungsi representasi simbolik, fungsi kontrol sosial, dan fungsi mendukung integrasi masyarakat. Sedangkan pembongkaran lirik lagu Slank secara tematis dapat ditemukan bahwa unsur tematis yang terdapat pada lirik lagu Slank digolongkan menjadi dua tema besar, yaitu tema personal dan sosial. Sedangkan unsur retoris dalam lirik lagu Slank lebih banyak menggunakan makna kata secara denotatif dibandingkan konotatif.

Berdasarkan ketiga penelitian terdahulu yang disebutkan di atas maka dapat dilihat beberapa perbedaan yang signifikan yaitu

1. Penelitian tidak menemukan penelitian tentang band Slank dengan menggunakan semiotik sebagai pisau analisis khususnya pada lirik lagu Kritis BBM dan mengkaitkannya dengan realitas sosial dampak kenaikan harga Bahan Bakar Minyak (BBM).

2. Meskipun ada penelitian Nurahim (Skripsi, tahun 2009) tentang lirik lagu Kritis BBM karya Slank namun pisau analisis yang dia gunakan adalah analisis linguistik serta tidak hanya pada satu lirik lagu tersebut saja.

3. Penelitian Siti Ainum Sakiman berlandaskan paradigma penelitian analisis wacana kritis yang bertujuan untuk mengintegrasikan kajian budaya kritis ke dalam proses komunikasi politik. Sedangkan penelitian ini akan membahas lirik lagu sebagai refleksi sosial sebagai bentuk dari konstruksi realitas sosial yang terkandung secara konotatif dan denotatif pada lirik lagu Kritis BBM karya Slank.

4. Penelitian Panji Suryo Nugroho yang menggunakan analisis semiotika guna menangkap makna yang terdapat dalam tanda-tanda, kode-kode kultural, serta konteks kebudayaan lahir produk pop religi Ungu. Sedangkan penelitian ini membahas mengenai realitas sosial bukan budaya yang menjadi realitas. Hal inilah yang menunjukkan kontekstual pembahasan sesuai dengan perkembangan informasi dan globalisasi masa kini.

Jadi dari beberapa penelitian terdahulu yang disebutkan di atas, peneliti yakin bahwa penelitian ini adalah autentik pembahasan dan merupakan sesuatu yang layak untuk diteliti. Menggunakan analisa semiotika sebagai pisau pembedah permasalah realitas sosial melalui kajian lirik lagu Kritis BBM karya Slank merupakan sesuatu yang patut diungkap makna yang tersembunyi sebagai refleksi dari realitas sosial pada masayarakat Indonesia. 


\section{Pengertian Konstruksi}

Istilah konstruksi sosial atas realitas (social construction of reality) didefinisikan Berger dan Luckmann (1991: 65-66) sebagai proses sosial melalui tindakan dan interaksi dimana individu menciptakan secara terus-menerus suatu realitas yang dimiliki dan dialami bersama secara subjektif. Pemakaian istilah tersebut digunakan untuk menggambarkan realitas sosial dalam perpektif Berger dan Luckmann secara objektif terhadap aktivitas masyarakat (activity) kemudian menjadi kebiasaan (tradition) sehingga menjadi sebuah aturan yang berlaku (institutional roles).

Asal usul konstruksi sosial menurut Suparno (1997: 24) dari filsafat konstruktivisme yang dimulai dari gagasan-gagasan konstruktif kognitif. Menurut Von Glasersfeld, pengertian konstruktif kognitif muncul dalam tulisan Mark Baldwin yang secara luas diperdalam dan disebarkan oleh Jean Piaget. Namun apabila ditelusuri, sebenarnya gagasan-gagasan pokok konstruktivisme sebenarnya telah dimulai oleh Giambatissta Vico, seorang epistemologi dari Italia, ia adalah cikal bakal Konstruktivisme.

Aliran filsafat dalam menggagas konsep konstruktivisme telah muncul sejak Socrates menemukan jiwa dalam tubuh manusia, sejak Plato menemukan akal budi dan id. Gagasan Bertens (1999: 89-106) tersebut semakin lebih konkret lagi setelah Aristoteles mengenalkan istilah, informasi, relasi, individu, subtansi, materi, esensi, dan sebagainya. Ia mengatakan bahwa, manusia adalah makhluk sosial, setiap pernyataan harus dibuktikan kebenarannya, bahwa kunci pengetahuan adalah fakta. Lebih lanjut Bertens (1999: 137) mengemukakan Aristoteles pulalah yang telah memperkenalkan ucapannya 'cogito ergo sum' yang berarti "saya berfikir karena itu saya ada". Kata-kata Aristoteles yang terkenal itu menjadi dasar yang kuat bagi perkembangan gagasan-gagasan konstruktivisme sampai saat ini.

Pada tahun 1710, Vico dalam Suparno, (1997: 24) mengungkapkan filsafatnya dengan berkata 'Tuhan adalah pencipta alam semesta dan manusia adalah tuan dari ciptaan'. Dia menjelaskan bahwa 'mengetahui' berarti 'mengetahui bagaimana membuat sesuatu' ini berarti seseorang itu baru mengetahui sesuatu jika ia menjelaskan unsur-unsur apa yang membangun sesuatu itu. Menurut Vico bahwa hanya Tuhan sajalah yang dapat mengerti alam raya ini karena hanya dia yang tahu bagaimana membuatnya dan dari apa ia membuatnya, sementara itu orang hanya dapat mengetahui sesuatu yang telah dikontruksikannya.

\section{Jenis Konstruktivisme}

Suparno (1997:25) mengemukakan ada tiga jenis konstruktivisme yakni konstruktivisme radikal; realisme hipotesis; dan konstruktivisme biasa.

1. Konstruktivisme radikal

Jenis ini hanya dapat mengakui apa yang dibentuk oleh pikiran kita. Bentuk itu tidak selalu representasi dunia nyata. Kaum konstruktivisme radikal mengesampingkan hubungan antara pengetahuan dan kenyataan sebagai suatu kriteria kebenaran. Pengetahuan bagi mereka tidak merefleksi suatu realitas ontologisme obyektif, namun sebuah realitas yang dibentuk oleh pengalaman seseorang. Pengetahuan selalu merupakan konstruksi dari individu yang mengetahui dan tdak dapat ditransfer kepada individu lain yang pasif karena itu konstruksi harus dilakukan sendiri olehnya terhadap pengetahuan itu, sedangkan lingkungan adalah saran terjadinya konstruksi itu.

2. Realisme hipotesis

Jenis konstruksi ini berupa pengetahuan, dimaknai sebagai sebuah hipotesis dari struktur realitas yang mendekati realitas dan menuju kepada pengetahuan yang hakiki. 
Artinya kerangka jawaban awal dari sebuah pengetahuan akan diuji, dianalisis dan diteliti sehingga menghasilkan pengetahuan yang bersifat ilmiah.

3. Konstruktivisme biasa

Jenis ini mengambil semua bentuk konsekuensi dari konstruktivisme dan memahami pengetahuan sebagai gambaran dari realitas itu. Kemudian pengetahuan individu dipandang sebagai gambaran yang dibentuk dari realitas objektif dalam dirinya sendiri. Jadi individu tersebut berkaitan dengan realitas, atau individu tersebut adalah realitas dari konstruksi tersebut. Hal ini dapat dicontohkan pada konstruksi pesan komunikasi berdasarkan opini publik yang publikasikan oleh media massa.

\section{Konstruksi Realitas Sosial dalam Perspektif Komunikasi}

Konstruksi realitas sosial mengandung dimensi objektif dan subjektif. Basrowi (2002: 75-76) mengemukan ada dua hal yang menonjol melihat realitas peran media dalam dimensi objektif yakni pelembagaan dan legitimasi.

1. Pelembagaan

Realitas sosial pada mulanya terjadi ketika semua kegiatan manusia mengalami proses pembiasaan. Artinya tiap tindakan yang sering diulangi pada akhirnya akan menjadi suatu pola yang kemudian bisa direproduksi, dan dipahami oleh pelakunya sebagai pola yang dimaksudkan itu. Pelembagaan terjadi apabila suatu tipikasi yang timbal-balik dari tindakan-tindakan yang sudah terbiasa bagi berbagai tipe pelaku. Tiap tipikasi seperti itu merupakan suatu lembaga.

2. Legitimasi

Legitimasi menghasilkan makna-makna baru yang berfungsi untuk mengintegrasikan makna-makna yang sudah diberikan kepada proses-proses kelembagaan yang berlainan. Fungsi legitimasi adalah untuk membuat obyektivasi yang sudah dilembagakan menjadi tersedia secara obyektif dan masuk akal secara subjektif.

Hal ini mengacu kepada dua tingkat, pertama keseluruhan tatanan kelembagaan harus bisa dimengerti secara bersamaan oleh para pesertanya dalam proses-proses kelembagaan yang berbeda. Kedua, keseluruhan individu (termasuk di dalam media), yang secara berturut-turut melalui berbagai tatanan dalam tatanan kelembagaan harus diberi makna subjektif. Masalah legitimasi tidak perlu dalam tahap pelembagaan yang pertama, dimana lembaga itu sekedar fakta yang tidak memerlukan dukungan lebih lanjut. Tapi menjadi tak terelakkan apabila berbagai obyektivasi tatanan kelembagaan akan dialihkan kepada generasi baru. Di sini legitimasi tidak hanya sekedar soal "nilai-nilai" ia juga selalu mengimplikasikan "pengetahuan". (Basrowi, 2002: 132-134)

Kalau pelembagaan dan legitimasi merupakan dimensi obyektif dari realitas, maka internalisasi merupakan dimensi subyektifnya. Analisis Berger menyatakan, bahwa individu dilahirkan dengan suatu pradisposisi ke arah sosialitas dan ia menjadi anggota masyarakat. Titik awal dari proses ini adalah internalisasi, yaitu suatu pemahaman atau penafsiran yang langsung dari peristiwa objektif sebagai suatu pengungkapan makna. Kesadaran diri individu selama internalisasi menandai berlangsungnya proses sosialisasi.

\section{Konsep Realitas Sosial dalam Komunikasi}

Gagasan konstruksi terhadap realitas sosial telah dikoreksi oleh gagasan dekonstruksi yang melakukan interpretasi terhadap teks wacana yang terkenal dengan gagasan-gagasan deconstruction. Gagasan ini kemudian melahirkan tesis-tesis keterkaitan antara kepentingan (interest) dan metode penafsiran (interpretation) atas realitas sosial. Dalam dekonstruksi, kepentingan tertentu selalu mengarahkan kepada pemilihan metode 
penafsiran. Derrida (1978) kemudian menjelaskan bahwa interpretasi yang digunakan individu terhadap analisis sosial yang bersifat sewenang-wenang.

Gagasan-gagasan Derrida itu sejalan dengan gagasan Habermas (1972) bahwa terdapat hubungan strategis antara pengetahuan manusia (baik empirik-analiti, historis hermeneutik, maupun kritis) dengan kepentingan (teknis, praktis, atau yang bersifat emansifatoris) walau tidak dapat disangkal bahwa yang terjadi juga bisa sebaliknya bahwa pengetahuan adalah produk kepentingan. (Basrowi, 2002: 123)

Menurut Berger dan Luckmannn pengetahuan yang dimaksud adalah realitas sosial masyarakat, seperti konsep, kesadaran umum, wacana publik, sebagai hasil dari konstruksi sosial, realitas sosial dikonstruksi melalui proses eksternalisasi, objektivasi, dan internalisasi. Menurut Berger dan Luckmannn, konstruksi sosial tidak berlangsung dalam ruang hampa, namun sarat dengan kepentingan-kepentingan.

Menurut Marcuse dalam kutipan Basrowi (2002: 124) realitas penerimaaan wacana yang diciptakan oleh negara itu disebut "desublimasi represif". Orang merasa puas dengan wacana yang diciptakan oleh negara walaupun implikasinya dari wacana itu menindas intelektual dan kultural masyarakat. Hal ini juga berlaku pada peristiwa di Indonesia dengan munculnya kebijakan pemerintah menaikkan harga Bahan Bakar Minyak (BBM). Banyak rakyat dan masyarakat kecil di Indonesia merasa tertindas sebab kenaikan harga Bahan Bakar Minyak (BBM) mempengaruhi perekonomian mikro yakni pelonjakan harga bahan pangan di pasaran. Gejala seperti di atas tidak lain sebagai produk dari keberadaan rezim pemaknaan (regime of significance) yang cenderung melakukan dominasi dan hegemoni makna atas berbagai peristiwa, pengetahuan, kesadaran, dan wacana. Rezim dimaksud adalah sekelompok orang yang memiliki kekuasaan formal sebagai representasi dari penguasa negara.

Dengan demikian, maka dekonstruksi dan konstruksi sosial merupakan dua konsep gagasan yang senantiasa hadir dalam satu wacana perbincangan mengenai realitas sosial. Seperti perbincangan tentang kenaikan harga Bahan Bakar Minyak (BBM) diperbincangkan melalui media dan menjadi headline. Tidak hanya sebatas headline diberbagai media di Indonesia tetapi juga merambah ke dunia musik dengan munculnya lagu Slank yang mengkritisi kebijakan tentang menaikkan harga Bahan Bakar Minyak (BBM) berjudul 'Kritis $B B M$ '. Terfokus pada lagu Kritis $B B M$ karya Slank, di dalam lirik lagunya terdapat berbagai ungkapan yang menunjukkan tuntutan keadilan dan kepanikan sosial yang mengalami keterpurukan ekonomi. Hal ini menujukkan tanda bahwa lagu Kritis BBM karya Slank adalah produk sosial yang dikomunikasikan dalam bentuk seni musik.

\section{Sistem Tanda}

Hal terpenting dalam objektivasi adalah pembuatan signifikansi, yakni pembuatan tanda-tanda oleh manusia. Berger dan Luckmann (1991: 50) mengatakan bahwa, sebuah tanda (sign) dapat dibedakan dari objektivasi-objektivasi lainnya, karena tujuannnya yang ekplisit untuk digunakan sebagai isyarat atau indeks bagi pemaknaan subjektif, maka objektivasi juga dapat digunakan sebagai tanda, meskipun semula tidak dibuat untuk maksud itu.

Sebuah wilayah penandaan (signifikasi) menjembatani wilayah-wilayah kenyataan, dapat didefinisikan sebagai sebuah simbol dan modus linguistik, dengan apa trensendensi seperti itu dicapai, dapat juga dinamakan bahasa simbol. Kemudian pada tingkat simbolisme, signifikasi linguistik, terlepas secara maksimal dari "disini dan sekarang" dalam kehidupan sehari-hari. (Berger dan Luckmannn, 1991: 57) Oleh karena itu, bahasa 
memegang peranan penting dalam objektivasi terhadap tanda-tanda, dan bahkan tidak saja dapat memasuki wilayah de facto, melainkan juga a priory yang berdasarkan kenyataan lain, tidak dapat dimasuki dalam pengalaman sehari-hari, bagaikan kehadiran kawanan raksasa dari dunia lain. Agama, Filsafat, Kesenian, dan ilmu pengetahuan, secara historis merupakan sistem-sistem simbol paling penting semacam ini.

Bahasa Berger dan Luckmann (1991: 92) menurut merupakan alat simbolis untuk melakukan signifikasi, yang mana logika ditambahkan secara mendasar kepada dunia sosial yang diobjektivasi. Bahasa digunakan untuk memberi signifikasi pada makna-makna yang dipahami sebagai pengetahuan yang relevan dengan masyarakatnya, pengetahuan itu dianggap relevan bagi semua orang dan sebagian lagi hanya relevan bagi tipe-tipe orang tertentu saja. Lirik lagu Kritis BBM karya Slank memberikan signifikansi makna-makna yang dipahami audiens sebagai pengetahuan tentang kebijakan pemerintah, kondisi sosial dan perekonomian yang kian memburuk. (bakohumas.kominfo.go.id, 4 Juli 2013)

\section{Tahapan Proses Konstruksi}

Teori dan pendekatan konstruksi sosial atas realitas Berger dan Luckmann dalam Bungin (2007: 188-189) telah direvisi dengan melihat fenomena media massa sangat substantif dalam proses eksternalisasi, subyektivasi dan internalisasi inilah yang kemudian dikenal sebagai "konstruksi sosial media massa". Menurut perspektif ini tahapan-tahapan dalam proses konstruksi sosial media massa itu terjadi melalui: tahap menyiapkan materi konstruksi; tahap sebaran kostruksi; tahap pembentukan kosntruksi; tahap konfirmasi. Penjelasannya adalah sebagai berikut:

1. Tahap menyiapkan materi konstruksi: Ada tiga hal penting dalam tahapan ini yakni: keberpihakan media massa kepada kapitalisme, keberpihakan semu kepada masyarakat, keberpihakan kepada kepentingan umum.

2. Tahap sebaran konstruksi: prinsip dasar dari sebaran konstruksi sosial media massa adalah semua informasi harus sampai pada khalayak secara tepat berdasarkan agenda media. Apa yang dipandang penting oleh media, menjadi penting pula bagi pemirsa atau pembaca.

3. Tahap pembentukan konstruksi realitas. Pembentukan konstruksi berlangsung melalui: (1) konstruksi realitas pembenaran; (2) kedua kesediaan dikonstruksi oleh media massa ; (3) sebagai pilihan konsumtif.

4. Tahap Konfirmasi. Konfirmasi adalah tahapan ketika media massa maupun penonton memberi argumentasi dan akuntabilitas terhadap pilihannya untuk terlibat dalam pembentukan konstruksi. (Bungin, 2007: 14)

Pada kenyataanya, realitas sosial itu berdiri sendiri tanpa kehadiran individu baik di dalam maupun di luar realitas tersebut. Realitas sosial memiliki makna, manakala realitas sosial dikonstruksi dan dimaknai secara subjektif oleh individu lain sehingga memantapkan realitas itu secara obyektif. Individu mengkostruksi realitas sosial, dan merekonstruksinya dalam dunia realitas, memantapkan realitas itu berdasarkan subyektivitas individu lain dalam institusi sosialnya. (Bungin, 2007: 188-189)

\section{Mitos}

Sobur (2009: 128) menjelaskan bahwa mitos adalah berhubungan dengan tanda. Tanda itu menunjukkan, menjelaskan, dan memahami aspek tentang realitas. Kamus Oxford Advanced Learner's English Dictionary (1995:770) menjelaskan makna mitos sebagai berikut, (1a) cerita yang berasal dari masa lampau terutama yang terkait dengan sejarah awal dari orang-orang atau menjelasakan kejadian alam seperti adanya musim 
misalnya. (1b) cerita pada umumnya. (2) suatu benda atau orang yang khayal atau tidak nyata.

Mitos dapat ditangkap keberadaannya dalam berbagai masyarakat dunia termasuk di Yunani yang menjadi cikal bakal tradisi filsafat Barat modern. Pada perkembangan selanjutnya mitos dianggap telah dapat digeser dengan rasio seiring kelahiran tradisi filsafat. Filsafat Barat yang kemudian terus berkembang memasuki dunia Islam, abad pertengahan di Eropa, hingga memasuki era filsafat modern yang menurunkan ilmu pengetahuan dan teknologi yang makin meminggirkan jauh mitos tradisional.

\section{Lirik Lagu dan Paradigma Konstruktivisme}

Media berperan besar sebagai alat konstruksi pesan, begitu pula dengan lirik lagu yang termasuk dalam media massa. Bungin (2001: 33) mengatakan bahwa dalam penjelasan ontologi paradigma konstruksivis, realitas merupakan konstruksi realitas sosial yang diciptakan oleh individu. Namun demikian, kebenaran suatu realitas sosial bersifat nisbi, yang berlaku sesuai konteks spesifik yang dinilai relevan oleh pelaku sosial. Setiap orang mempunyai cara tersendiri bagaimana cara mengkonstruksi sebuah realitas yang ditampilkan dengan ungkapan lirik lagu.

Mengungkap proses konstruksi realitas sosial dalam sebuah karya seni tarik suara dalam hal ini dikhususkan pada liriknya, dapat dirujuk pada teori Sigmund Freud ketika menjelaskan proses psikis yang merupakan regresi dari pengaruh lingkungan. Freud menarik sebuah benang merah bahwa apa yang terjadi pada pribadi seseorang ketika melihat lingkungan masyarakat sebagai suatu kesenjangan, tidak luput dari pengalaman dan kerangka pemikirannya. Hal ini menurut Effendi (1997: 123) berkaitan dengan proses penyampaian field of experience dan frame of reference.

Asumsi Freud mengantarkan pada sebuah pemahaman dasar bahwa band Slank dalam menulis lirik lagunya Kritis $B B M$ adalah tidak lepas dari pengaruh realitas sosial lingkungan dimana ia berada. Realitas tersebut berupa kenaikan harga yang dicanangkan oleh pemerintah mempengaruhi perekonomian rakyat dengan naiknya harga bahan pokok di pasaran. Melalui landasan ini dapat mengungkapkan sebuah pandangan bahwa bentuk konstruksi realitas sosial dari lirik lagu Slank Kritis BBM adalah menafsirkan berbagai tanda dan penanda.

\section{Lirik Lagu dan Realitas Sosial Sebagai Tanda}

Fiske (1990: 40) mendefinisikan sign (tanda) adalah " a sign is something physical, perceivable by our senses; it refers to something other than itself; and it depends upon recognition by its users that it is a sign". Jadi Tanda adalah kesatuan yang dapat dipisahkan dari dua bidang seperti halnya selembar kertas yaitu bidang penanda (siginifier) untuk menjelaskan bentuk atau ekspresi; dan bidang petanda (siginified), untuk menjelaskan konsep atau makna:

\section{Signifier + Signified $=$ Sign}

Gambar 2.1 Konsep Sign menurut Fiske

Sumber: John Fiske (1990). Introduction to Communication Studies Second Edition, h. 40. 
Lagu dan musik merupakan paduan suara yang dapat mempengaruhi pendengarnya. Hal ini sejalan dengan ungkapan Frith dan Goodwin (2005: 10) bahwa:

This truism led me to the further conclusion that one cannot hope to understand the influence of any one medium, say music, without an understanding of the total character structure of a person. In turn, an understanding of his musical tastes, and his use of them for purposes of social conformity, advance, or rebellion, provides revealing clues to his character, to be confirmed and modified by knowledge of his behavior and outlook in many other spheres of life.

Berkaitan dengan apa yang disebutkan Frith dan Goodwin melalui musik seseorang dapat menunjukkan karakter seorang musisi sehingga dapat mempengaruhi pendengarnya. Oleh karena itu lirik lagu dalam perspektif komunikasi memiliki tujuan tertentu sehingga dapat dijadikan sebagai tanda (sign). Tanda-tanda itu termasuk sebagai sistem tanda yang bekerja sama dengan baik dalam upaya mencapai efek yang diharapkan. (Sobur, 2004: 128). Lirik lagu mempunyai makna yang sangat filosofis mengenai realitas sosial yang diungkapkan oleh musisinya, tapi bukanlah meneliti sebuah lirik lagu jika tidak dihubungkan dengan realitas sosial yang terkandung dalam lirik tersebut. Jadi dapat ditarik kesimpulan bahwa banyak tanda-tanda yang dibangun dalam sebuah lirik lagu.

\section{Semiotika Sebagai Pisau Analisis}

Pendekatan semiotika dipilih penulis karena semiotika dianggap mampu untuk menjelaskan berbagai hal yang tidak tampak dipermukaan, tapi lebih jauh dari itu, semiotika mampu untuk membongkar makna-makna yang tersembunyi sehingga kedalaman dan keluasan informasi akan sangat menentukan sejauh mana penggalian informasi yang diperoleh. Penulis melakukan penelitian terhadap tanda-tanda dalam lirik lagu Kritis BBM Karya Slank berdasarkan teori tanda yang dikemukakan oleh seorang filosof Amerika, Charles Sanders Pierce. Berdasarkan objeknya, Danessi (2004: 27) menjelaskan bahwa Pierce membagi tanda atas icon (ikon), index (indeks), dan symbol (simbol). Ikon adalah tanda yang hubungan antara signifier dan signified bersifat bersamaan bentuk alamiah. Atau dengan kata lain, ikon adalah hubungan antara tanda dan objek atau acuan yang bersifat kemiripan.

Indeks adalah tanda yang menunjukkan adanya hubungan alamiah antara signifier dan signified yang bersifat kausal atau hubungan sebab akibat, atau tanda yang langsung mengacu pada kenyataan. Sobur (2004: 24) menambahkan bahwa tanda dapat mengacu ke denotatum melalui konvensi. Tanda seperti itu adalah tanda konvensional yang biasa juga disebut simbol, jadi simbol adalah tanda yang menunjukkan hubungan alamiah antara signifier dan signified. Hubungan ini berdasarkan konvensi (kesepakatan) masyarakat.

Pendekatan yang dipilih oleh penulis adalah pendekatan dua tahap Barthes berupa denotasi kemudian konotasi. Pendekatan Barthes dianggap mempunyai kelebihan sebab pendekatan ini selalu berpotensi untuk menemukan sesuatu yang lebih dari sekedar bahasa (other of signification). (Piliang, 2003: 261, dan Kriyantono, 2008: 270)

Denotasi adalah tingkat pertandaan yang menjelaskan hubungan antara signifier dan signified, atau antara tanda dan rujukannya pada realitas, yang menghasilkan makna yang eksplisit, langsung, dan pasti. Sedangkan konotasi adalah tingkat pertandaan yang menjelaskan hubungan antara signifier dan signified, yang di dalamnya beroperasi makna yang tidak eksplisit, tidak langsung, dan tidak pasti (artinya terbuka bagi segala kemungkinan). Barthes menciptakan peta tentang bagaimana tanda bekerja. 


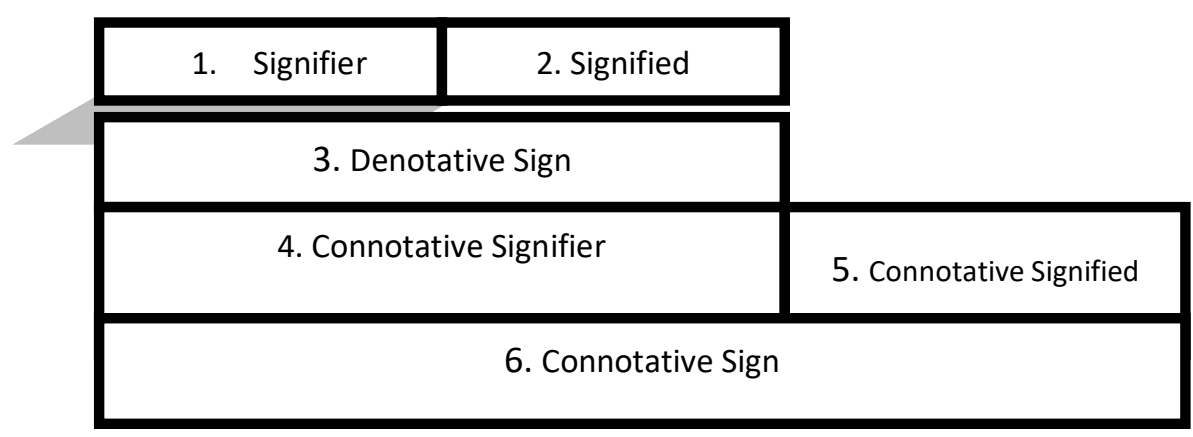

\section{Gambar 2.2 Peta Tanda Roland Barhtes \\ Sumber:Kerangka Barthes dalam Alex Sobur (2004) Analisis Teks Media Suatu Pengantar untuk Analisis Wacana, Analisis Semiotik, dan Analisis Framing, h. 69.}

Dari peta tanda Roland Barthes tersebut, dapat dikatakan bahwa makna denotasi yang membangun makna konotasi dari tanda tersebut. Jadi, dalam konsep Barthes, tanda konotatif tidak sekedar memiliki makna tambahan, namun juga mengandung kedua bagian tanda denotatif yang melandasi keberadaannya. Di dalam semiologi Roland Barthes dan para pengikutnya, denotasi merupakan sistem signifikansi tingkat pertama, sementara konotasi merupakan tingkat kedua. Denotasi dalam hal ini justru lebih diasosiasikan dengan ketertutupan makna, sensor atau represi politis. Sebagai reaksi yang paling ekstrem melawan keharfiahan denotasi yang bersifat opresif dan menindas kebebasan berpendapat, Barthes mencoba menyingkirkan dan menolaknya. Baginya yang ada hanyalah konotasi semata-mata.

Peneliti berpijak pada teori yang dikemukakan oleh Barthes tersebut, dan menganggap bahwa lirik lagu Kritis BBM karya Slank yang diteliti yakni kaya akan tanda yang bisa dijelaskan dan siginifikan dengan teori tersebut, teori ini dapat membongkar konstruksi realitas sosial, maka dengan itu penulis menggambarkan kerangka pikir yang kelak akan menjadi acuan dalam penyusunan tesis ini. Kerangka berpikir tersebut adalah sebagai berikut:

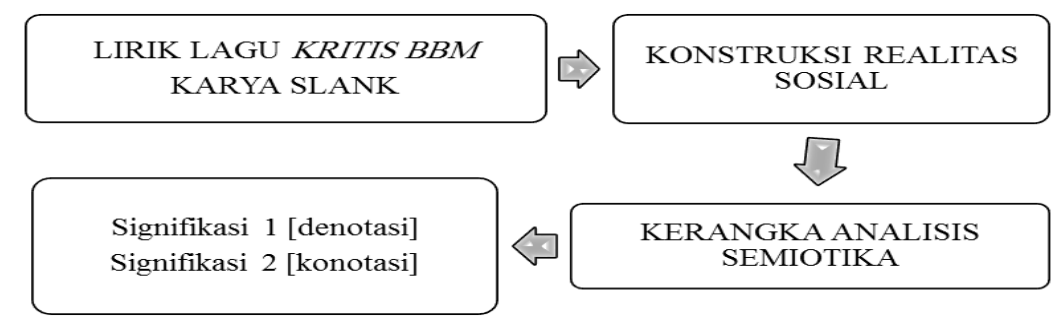

Gambar 2.3. Kerangka Pemikiran Peneliti

Sumber: Desain kerangka pikir peneliti dalam menginterpretasikan penelitian.

\section{Metode}

Penelitian kualitatif didasarkan pada upaya konstruksi terhadap informasi yang diteliti. Sejalan dengan Richie dalam Moleong bahwa penelitian kualitatif berupaya menyajikan realitas sosial dan perspektif-perspektif di dalamnya berdasarkan konsep, perilaku, persepsi, dan dinamika di dalamnya. Berdasar pada pandangan Bogdan dan Taylor, Denzin dan Lincoln, Richie serta beberapa penulis lainnya, Moleong (2010: 4-6). 
Lebih lanjut dijelaskan Moleong bahwa penelitian kualitatif dapat digunakan untuk merangkai fenomena, menelaah, menafsirkan isu-isu rinci tentang stuasi dan kenyataan.

Selama proses pengumpulan data lebih bersifat induktif, dan teori dibangun dari data. Denzin dan Lincoln yang menyatakan penelitian kualitatif dapat melibatkan berbagai metode, maka penelitian ini menggunakan dua jenis metode penelitian yaitu metode deskriptif dan metode analisis semiotik. Metode deskriptif digunakan untuk menerangkan realitas sosial kenaikan harga bahan bakar minyak pada tahun 2013 dan perjalanan musik Slank dalam peta musik Indonesia. Metode analisis semiotik digunakan untuk melihat hubungan antara teks lirik lagu Slank dengan realitas sosial dampak kenaikan harga bahan bakar minyak.

Penggunaan kedua metode tersebut berdasarkan pendapat Moleong (2010: 9-10) dalam menggunakan metode kualitatif dapat disesuaikan pendekatan yang digunakan dalam menyajikan secara langsung dinamika dalam sebuah realita. Metode deskriptif dapat diartikan oleh Nawawi (2007: 67) sebagai prosedur pemecahan masalah yang diselidiki dengan menggambarkan, melukiskan keadaan subjek atau objek penelitian pada saat sekarang berdasarkan fakta-fakta yang tampak, atau sebagaimana adanya. Adapun data dalam penelitian ini adalah berdasarkan sumbernya adalah data teks yaitu data kualitatif yang berasal dari teks-teks tertentu. Kriyantono membahas sistem tanda dengan kajian komunikasi yang di dalamnya terdapat simbol realitas sosial. Oleh karena itu, data penelitian ini berdasarkan sumbernya adalah lirik lagu sebagai teks. Membedakan data penelitian kualitatif, menurut Kriyantono (2008: 38) dibagi menjadi dua, yaitu data primer dan data sekunder. Data primer berupa dokumentasi teks lagu Slank yang berjudul "Kritis $B B M$ " karya Slank pada album Slankisme. Sedangkan data sekunder menurut Kriyantono (2008: 42) adalah data teks yang diperoleh dari pihak kedua yang bersifat melengkapi data primer. Adapun data sekunder dalam penelitian adalah dokumen yang berhubungan dengan realitas sosial kenaikan harga BBM. Dokumen tersebut bisa berasal dari dokumen resmi pemerintah atau dokumen pribadi peneliti sendiri yang berkaitan dengan penelitian.

Penelitian ini dilandasi asumsi bahwa lirik lagu adalah produk sosial, di dalamnya terdapat simbol-simbol konstruktif menyampaikan maksud tertentu bagi audiensnya. Teks di sini dipahami dalam pengertian yang luas apalagi memandang lirik lagu sebagai teks dan sistem tanda. Untuk kepentingan penelitian ini, pandangan umum mengenai teks atau lirik lagu perlu difokuskan pada interpretasi lirik sesuai dengan mitos yang terkandung di dalam lirik itu sendiri.Pengkategorian kategori teks lirik lagu Kritis BBM sebagai bentuk identifikasi teks agar dapat menentukan unit-unit yang akan dianalisa. Kategori tersebut dapat dilihat pada tabel berikut ini:

Tabel 1.1

Kategori dan Pertimbangan Unit Analisis pada Lirik Lagu Kritis BBM karya Slank

\begin{tabular}{|l|l|l|}
\hline No & \multicolumn{1}{|c|}{ Unit Analisis } & \multicolumn{1}{c|}{$\begin{array}{c}\text { Pertimbangan Berasarkan } \\
\text { Tujuan Komunikas }\end{array}$} \\
\hline 1. & Kalimat & $\begin{array}{l}\text { Kalimat mewakili kandungan pesan komunikasi tentang } \\
\text { realitas sosial pada lirik lagu }\end{array}$ \\
\hline 2. & Istilah & $\begin{array}{l}\text { Penekanan dan kekhasan dari kata yang digunakan dalam } \\
\text { kalimat pada lirik lagu }\end{array}$ \\
\hline 3. & Pungtuasi meliputi: & $\begin{array}{l}\text { Mencerminkan kekhasan dari tanda dari lirik lagu sehingga } \\
\text { berkonotasi pada ide realitas teks. } \\
\text { Tanda titik sebagai bentuk penekanan makna dan } \\
\text { masalah, jika titik yang digunakan terdiri dari dua atau } \\
\text { lebih }\end{array}$ \\
\hline
\end{tabular}




\begin{tabular}{|c|c|c|}
\hline & $\begin{array}{l}\text { b. Tanda Tanya } \\
\text { c. Tanda Seru } \\
\text { d. Huruf Kapital }\end{array}$ & $\begin{array}{l}\text { 2. Tanda tanya untuk menekan komunikasi persuasif } \\
\text { dalam mengungkap permasalahan yang harus dijawab } \\
\text { 3. Tanda seru untuk menekankan pemaknaan yang } \\
\text { emosional tentang suatu permasalahan } \\
\text { 4. Huruf kapital yang digunakan pada kata-kata yang } \\
\text { mengandung arti khusus dan istimewa }\end{array}$ \\
\hline 5. & Bahasa Non Formal & Proximity (kedekatan antara lirik lagu dengan audien) \\
\hline 6. & $\begin{array}{l}\text { Cerita meliputi } \\
\text { a. Alur cerita } \\
\text { b. Latar Setting }\end{array}$ & $\begin{array}{l}\text { Alur cerita mendekatkan proses terjadinya masalah dengan } \\
\text { melihat jalan cerita dan yang melatar belakanginya. Maka } \\
\text { pemaknaan terhadap realitas sosial dalam cerita pada lirik } \\
\text { lagu Kritis } B B M \text { yang ada pada bagian akhir lirik. }\end{array}$ \\
\hline
\end{tabular}

Sumber: Adopsi dari Keraf (1977), Komposisi, h. 22-35

Penelitian dengan menggunakan dokumen sebagaimana Moleong (2010: 219) menyebutkan dengan istilah dokumen resmi, kemudian membaginya menjadi dua jenis yaitu "dokumen internal untuk kalangan sendiri dan dokumen eksternal berisi bahan informasi yang dihasilkan oleh suatu lembaga". Jadi jenis dokumen resmi yang dijadikan sebagai dokumen dalam penelitian ini. Selain dokumen resmi Moleong (2010: 217) juga menyebutkan adanya penggunaan dokumen pribadi sebagai sumber data dokumen. Oleh K karena itu peneliti juga menggunakan dokumen pribadi berupa koleksi album dan lirik lagu Kritis $B B M$ yang bersumber dari official website Slank sebagai file data primer yang dikoleksi oleh peneliti sendiri. Analisis data yang dipakai dalam penelitian ini adalah analisis semiotika. Menggunakan analisis semiotika Roland Barthes untuk menganalisis makna-makna yang tersirat dari pesan komunikasi yang disampaikan dalam bentuk lambang. Pada dasarnya pemikiran Barthes benar-benar dipengaruhi oleh Saussure (1983: 64), yaitu sebuah tanda adalah kombinasi dari signifier dan signified dan suatu tanda tidak berdiri sendiri tapi merupakan bagian dari suatu sistem. Signifier adalah bunyi yang bermakna atau coretan yang bermakna (aspek material), yakni apa yang dikatakan dan apa yang ditulis atau dibaca. Signified adalah gambaran material, yakni pikiran atau konsep aspek mental dari bahasa keduanya merupakan dua aspek yang tidak dapat dipisahkan seperti dua sisi mata uang. Hubungan antara keberadaan fisik tanda dan konsep mental tersebut dinamakan signification, dengan kata lain signification adalah upaya dalam memberi makna terhadap dunia. (Sobur, 2009: 125) Ritzer (2010) mengutip pendapat Barthes berpendapat bahwa bahasa adalah sebuah sistem tanda yang mencerminkan asumsi-asumsi dari suatu masyarakat tertentu dalam waktu tertentu. Metode semiotika dalam mengkaji lirik lagu Kritis BBM karya Slank untuk direpresentasikan dalam kehidupan nyata, sehingga diperoleh makna tertentu. Semiotika digunakan sebagai pendekatan untuk menganalisis teks media dengan asumsi bahwa media itu sendiri dikomunikasikan melalui seperangkat tanda.

Teori Barthes tentang gagasan dua tatanan pertandaan (order of signification) terdiri dari denotasi, tatanan ini menggambarkan relasi antara penanda dan pertanda di dalam tanda, dan antara tanda dan referennya dalam realitas eksternal. Barthes menyebut tatanan ini sebagai denotasi. Hal ini mengacu pada pendapat umum, makna jelas tentang tanda. Konotasi, dalam istilah yang digunakan Barthes, konotasi dipakai untuk menjelaskan salah satu dari tiga cara tanda dalam tatanan pertanda kedua.

Tahap akhir dari analisis suatu data adalah mengadakan pemeriksaan kebenaran data. Data yang telah dipilih kemudian dianalisa dengan landasan teori yang telah ditentukan sebelumnya. Langkah-langkah yang akan diambil dalam menganalisa data adalah sebagai berikut: 
1. Menganalisa hubungan antara penanda (signifier) dengan petanda (signified); antara bentuk atau ekspresi lirik lagu Kritis BBM dengan makna yang terkandung di dalamnya.

2. Mengindentifikasi setiap tanda pada lirik lagu Kritis $B B M$ yang berkaitan dengan realitas sosial.

3. Menganalisa denotasi dan konotasi dari lirik lagu Kritis BBM karya Slank Adapun kerangka analisa secara teknis dalam lirik lagu Kritis BBM menggunakan kerangka analisis kontekstual yang dijelaskan pada tabel berikut ini:

Tabel 1.2

Kerangka Analisa Teks Secara Kontekstual

\begin{tabular}{|l|l|l|}
\hline \multicolumn{1}{|c|}{ Kerangka } & \multicolumn{1}{c|}{ Metode } & \multicolumn{1}{c|}{ Konteks } \\
\hline Medan Wacana & $\begin{array}{l}\text { Menganalisa tema, isi dan } \\
\text { kandungan }\end{array}$ & $\begin{array}{l}\text { Realitas sosial kenaikan harga } \\
\text { Bahan Bakar Minyak (BBM) }\end{array}$ \\
\hline Penyampai Wacana & $\begin{array}{l}\text { Menganalisa sifat, tokoh } \\
\text { yang dimunculkan. }\end{array}$ & $\begin{array}{l}\text { Citra, kritis, sinis, bahasa halus } \\
\text { persuasif, dan tegas }\end{array}$ \\
\hline Mode Wacana & $\begin{array}{l}\text { Penggunaan bahasa, } \\
\text { istilah dan tanda baca }\end{array}$ & $\begin{array}{l}\text { Kesan dari tanda yang } \\
\text { digunakan }\end{array}$ \\
\hline
\end{tabular}

Sumber: Diadaptasi dari Moleong (2010), Analisis Teks Media ...h. 151-154.

4. Menganalisa kandungan tanda relevan dengan komunikasi dalam lirik lagu Kritis BBM karya Slank dengan realitas sosial kenaikan harga bahan bakar minyak (BBM).

5. Berdasarkan analisa-analisa tersebut diambil kesimpulan yang berkaitan dengan halhal yang maksud dari penelitian ini. (Sobur, 2009: 154).

\section{Hasil dan Pembahasan}

Gambaran kenaikan harga bahan bakar minyak dalam hal ini adalah untuk menjelaskan realitas sosial. Untuk melihat secara nyata bahwa kenaikan harga merupakan hal yang urgen dalam perkembangan perekonomian di Indonesia. Gambaran ini akan menjelaskan seluk-beluk yang melatarbelakangi kenaikan harga, peraturan pemerintah dan dampaknya.

Identifikasi terhadap teks lirik lagu Kritis $B B M$ memiliki ciri dan kekhasan dari setiap bait-bait teksnya. Peneliti dalam hal ini akan mengidentifikasi kalimat demi kalimat dengan melihat tanda denotasi dan konotasi terhadap konstruksi realitas sosial kenaikan harga Bahan Bakar Minyak (BBM). Kekhasan wacana realitas sosial dalam lirik tersebut diungkap dalam bentuk konstruksi realitas sosial melalui kacamata semiotika Barthes, dengan pertimbangan tanda baca, penggunaan istilah, sifat dari wacana, dan medan wacana yang menjadi sorotan utama menjabarkan konstruksi realitas sosial dalam lirik lagu Kritis $B B M$ karya Slank.

Tabel 1.3. Identifikasi Lirik Lagu Kritis BBM Karya Slank

\begin{tabular}{|l|l|c|l|l|}
\hline \multirow{2}{*}{ No } & \multicolumn{1}{|c|}{ Lirik Lagu Kritis $\boldsymbol{B B M}$} & \multirow{2}{*}{$\begin{array}{c}\text { Kandungan } \\
\text { Semiotika }\end{array}$} & \multicolumn{1}{|c|}{ Pola Semiotika } \\
\cline { 4 - 5 } & & Konotasi & $\begin{array}{l}\text { Huruf Kapital, tanda } \\
\text { bacan titik, }\end{array}$ & Regenerasi Masa Depan \\
\hline 1. & $\begin{array}{l}\text { GENERASI... MASA } \\
\text { DEPAN }\end{array}$ & $\begin{array}{l}\text { Denotasi dan } \\
\text { Konotasi }\end{array}$ & $\begin{array}{l}\text { Bahasa Non Formal, } \\
\text { Huruf Kapital, tanda } \\
\text { baca titik, tanda seru }\end{array}$ & $\begin{array}{l}\text { Masa Depan Pendidikan dan } \\
\text { Kesehatan }\end{array}$ \\
\hline 2. & $\begin{array}{l}\text { Gak } \\
\text { BERPENDIDIKAN...PENY } \\
\text { AKITAN! }\end{array}$ & Denotasi & $\begin{array}{l}\text { Huruf Kapital, tanda } \\
\text { baca titik }\end{array}$ & $\begin{array}{l}\text { Dampak Kenaikan Harga } \\
\text { Bahan Bakar Minyak (BBM) } \\
\text { bagi Rakyat Miskin }\end{array}$ \\
\hline 3. & $\begin{array}{l}\text { BBM naik Rakyatnya jadi } \\
\text { pada miskin .. }\end{array}$ & Denotasi dan & Bahasa non formal, & Hegemoni Sosial pada Rakyat \\
\hline 4
\end{tabular}


Vol 1 No. 1, 2018, 97-130

DOI: https://doi.org/10.30596/persepsi.v1i1.2510

\begin{tabular}{|c|c|c|c|c|}
\hline & DPR minta naik gaji ..” & Konotasi & $\begin{array}{l}\text { tanda koma, tanda baca } \\
\text { titik, tanda kutip }\end{array}$ & Miskin Versus Legislatif \\
\hline 5. & $\begin{array}{l}\text { BBM naik Rakyat gak punya } \\
\text { apa-apa .. }\end{array}$ & $\begin{array}{c}\text { Konotasi dan } \\
\text { Denotasi }\end{array}$ & $\begin{array}{l}\text { Hurup kapital, tanda } \\
\text { baca titik }\end{array}$ & $\begin{array}{l}\text { Taraf Hidup Rakyat Miskin } \\
\text { Semakin Susah }\end{array}$ \\
\hline 6. & Diminta hidup sederhana .. & Konotasi & $\begin{array}{l}\text { Bahasa formal, tanda } \\
\text { baca titik }\end{array}$ & $\begin{array}{l}\text { Hegemoni Sosial Rakyat } \\
\text { Miskin dengan Konsep Hidup } \\
\text { Sederhana }\end{array}$ \\
\hline 7. & $\begin{array}{l}\text { Rakyat Menderita Pejabat } \\
\text { Memperkaya Diri }\end{array}$ & Denotasi & Huruf Kapital & $\begin{array}{l}\text { Rakyat Menderita Pejabat } \\
\text { Memperkaya Diri }\end{array}$ \\
\hline 8. & $\begin{array}{l}\text { BBM naik hidup penuh tanda } \\
\text { tanya? }\end{array}$ & $\begin{array}{l}\text { Denotasi dan } \\
\text { Konotasi }\end{array}$ & Tanda tanya & $\begin{array}{l}\text { Kebijakan Pemerintah Tidak } \\
\text { Transparan }\end{array}$ \\
\hline 9. & Kelebihan dananya kemana? & Konotasi & Tanda tanya & $\begin{array}{l}\text { Tuntutan Rakyat Terhadap } \\
\text { Tranparansi Pemerintah }\end{array}$ \\
\hline 10. & $\begin{array}{l}\text { Tambah noda Hitam } \\
\text { PERTAMINA .. oya ! AHA }\end{array}$ & Konotasi & $\begin{array}{l}\text { Tanda baca titik, bahasa } \\
\text { non formal, tanda seru }\end{array}$ & $\begin{array}{l}\text { Citra Buruk PERTAMINA } \\
\text { Sebagai Ladang Korupsi }\end{array}$ \\
\hline 11. & $\begin{array}{l}\text { BBM naik Kepanikan di } \\
\text { mana-mana ! panik di POM- } \\
\text { POM Bensin, Panik orang } \\
\text { menuntut dana kompensasi .. }\end{array}$ & Denotasi & $\begin{array}{l}\text { Huruf kapital, tanda } \\
\text { seru, tanda koma, tanda } \\
\text { baca titik. }\end{array}$ & $\begin{array}{l}\text { Goncangan Stabilitas Sosial } \\
\text { bagi Rakyat Miskin }\end{array}$ \\
\hline 12. & $\begin{array}{l}\text { Cerita Ahmad Saleh } \\
\text { dalam Lirik Lagu Kritis BBM } \\
\text { Karya Slank }\end{array}$ & $\begin{array}{l}\text { Konotasi dan } \\
\text { Denotasi }\end{array}$ & Cerita, alur, latar setting & $\begin{array}{l}\text { Cerita Dibalik Kecurangan } \\
\text { Alokasi Bantuan Dana } \\
\text { Kompensasi }\end{array}$ \\
\hline
\end{tabular}

Sumber: Pengolahan peneliti data teks lirik lagu Kritis BBM karya Slank

\section{Generasi...masa depan}

Ungkapan ini berusaha menggambarkan "generasi" sebagai penerus masa depan bangsa. Generasi sendiri dimaknai dalam Kamus Bahasa Indonesia sebagai kelompok, golongan yang meneneruskan generasi sebelumnya. Secara konotatif medan wacana yang dipakai dalam ungkapan ini mencoba mengungkapkan bahwa generasi bangsa Indonesia harus sadar dalam memahami realitas sosial kenaikan harga Bahan Bakar Minyak (BBM) merupakan contoh dari sekian banyak permasalahan bangsa Indonesia utamanya di bidang ekonomi.

Penyampaian wacana dalam lirik lagu Kritis $B B M$ mencoba mengetuk hati generasi bangsa dengan ungkapan "generasi...masa depan". Secara konotatif ungkapan ini menunjukkan sikap persuasif dan emosional dalam lirik lagu Kritis BBM secara tegas menyeru dan menghimbau bahwa kelompok yang disebut sebagai generasi harus sadar akan realitas sosial kenaikan harga bahan bakar minyak merupakan masalah bangsa.

Peran bahasa yang digunakan dalam lirik lagu Kritis BBM menunjukkan seruan sekaligus himbauan kepada audiens (pendengar lagu Kritis BBM). Kata yang menunjukkan tersebut adalah "Generasi" kemudian merujuk pada masa depan. Kata "generasi" ini juga merupakan salah satu bentuk penggunaan huruf kapital dimaknai istimewa, yakni memiliki makna yang lebih khusus sehingga lebih dominan ditujukan pada golongan kaum muda. Kesan ini semakin kuat tatkala muncul kata "Masa depan", maka secara denotatif merujuk pada generasi muda artinya generasi yang melanjutkan generasi sebelumnya. Aspek penekanan dalam ungkapan ini ditandai dengan tiga titik setelah kata generasi menunjukkan kesan penekanan kepada generasi yang dimaksudkan dalam ungkapan lirik ini. Jika ada penekanan dalam suatu ungkapan tentunya merupakan suatu bentuk komunikasi yang tegas dan persuasif dalam penyampaian pesannya. Dari penjelasan kerangka analisis semiotika di atas jika disimpulkan secara konstruktif dapat dilihat pada tabel berikut ini: 
Tabel 1.4.Penafsiran Secara Kontekstual Pada Ungkapan "GENERASI... MASA DEPAN"

\begin{tabular}{|c|l|l|}
\hline No & \multicolumn{1}{|c|}{ Kerangka Analisis } & \multicolumn{1}{c|}{ Uraian } \\
\hline 1. & Medan Wacana & $\begin{array}{l}\text { Adanya realitas sosial kenaikan harga Bahan } \\
\text { Bakar Minyak bagi regenerasi masa depan. }\end{array}$ \\
\hline 2. & Penyampai Wacana & $\begin{array}{l}\text { Sifat penyampai pesan dikomunikasikan } \\
\text { dengan aspek penekanan pada kata generasi } \\
\text { dan ketegasan dalam mengungkapkannya }\end{array}$ \\
\hline 3. & Mode Wacana & $\begin{array}{l}\text { Huruf kapital, Tanda baca titik tiga setelah } \\
\text { kata "generasi" diperjelas maknanya dengan } \\
\text { ungkapan "masa depan" }\end{array}$ \\
\hline
\end{tabular}

Dari pembahasan di atas dapat gambarkan bahwa denotasi dari ungkapan "Generasi...Masa Depan" adalah generasi yang akan merasakan konsekuensi dari kenaikan harga bahan bakar minyak di masa yang akan datang. Tidak diketahui sampai kapan akan tetapi generasi masa depan yang dimaksud tidak memiliki masa depan. Dalam hal ini Slank seolah-olah berperan sebagai peramal.

Secara konotatif, mengungkapkan komunikasi persuasif dari ungkapan lirik lagu Kritis $B B M$ terhadap kalangan muda sebagai orang yang dapat memahami realitas sosial kenaikan harga sebagai salah satu masalah bangsa di bidang perekonomian. Melalui lirik lagu Kritis BBM komunikator (Slank) mencoba menggugah para audiennya agar sadar akan permasalahan tersebut.

\section{Gak Berpendidikan.... Penyakitan!}

Medan wacana yang dimunculkan dalam penggalan lirik lagu ini berusaha menggambarkan masalah realitas sosial yang akan dihadapi oleh kalangan muda. Hal ini dilihat pada pemaknaan kata "Gak" yang berarti tidak. Realitas sosial tersebut adalah berupa masalah pendidikan dan kesahatan. Secara denotatif pemaknaan berpendidikan sudah jelas adalah masalah di bidang pendidikan. Selanjutnya berpenyakitan secara konotatif menunjukkan kesan berpenyakit. Jika berpenyakit tentunya permasalahan yang dimaksudkan adalah masalah kesehatan. Untuk itu medan wacana yang diungkapkan adalah berkaitan dengan masa depan generasi muda yakni pendidikan dan kesehatan.

Pada kerangka penyampai wacana dalam ungkapan "Gak Berpendidikan....Penyakitan!" Mengandung beberpa sifat yakni penekanan dan kritis. Sifat penekanan ditujukan pada aspek pendidikan bagi para kalangan muda. Jika dikaitkan dengan masalah pendidikan tentunya sangat luas, jadi pemaknaan pendidikan dalam ungkapan ini adalah terfokus pada unsur pendidikan sebagaimana ungkapan generasi pada lirik sebelumnya maka kesan yang muncul dalam pendidikan adalah peserta didik. Jika peserta didik dalam hal ini sebagai unsur pendidikan belum mendapat pendidikan yang layak. Pada aspek kritis dalam ungkapan lirik ini menunjukkan adanya kritis terhadap masalah kesehatan dan berbagai prosedur yang dilaksanakan pemerintah belum mencapai target dan tujuan kepada kalangan muda yang dianggap jarang memiliki penyakit karena kondisi badan yang masih sehat bugar. Padahal realitasnya banyak anak yang tidak mendapatkan makanan yang bergizi sehingga timbul masalah gizi buruk.

Mode wacana dalam penggalan lirik "Gak Berpendidikan... Penyakitan! Diawali dengan bahasa pasaran atau bahasa non formal. Hal ini tentunya secara bahasa memberikan tanda komunikasi yang menyatakan "tidak", artinya jika diungkapkan 
kembali ungkapan ini secara denotatif maka yang mucul adalah "tidak berpendidikan" dan "tidak sehat" atau "memiliki penyakit di dalam tubuhnya". Jika hal ini merupakan bentuk tanda secara konotatif maka ungkapan ini memberi kesan komunikasi yang tegas dan kritis terhadap masalah pendidikan dan kesahatan. Tanda selanjutnya adalah munculnya penggunaan titik sebanyak tiga, memberi arti bahwa masalah pendidikan adalah penting, sendangkan tanda seru pada akhir kata "Penyakitan" menunjukkan tanda pernyataan yang emosional dan kritis. Tanda selanjutnya adalah huruf kapital pada ungkapan "Berpendidikan" dan "Penyakitan" memberi kesan bahwa kedua masalah tersebut adalah masalah yang besar dan harus mendapat penanganan yang istimewa dibanding dengan masalah lainnya.

Berdasarkan pembahasan di atas dapat diambil apa saja rangkaian pembahasannya dalam bentuk tampilan tabel berikut:

Tabel 1.5. Penafsiran Secara Kontekstual Pada Ungkapan "Gak Berpendidikan...Penyakitan"

\begin{tabular}{|c|l|l|}
\hline No & \multicolumn{1}{|c|}{ Kerangka Analisis } & \multicolumn{1}{c|}{ Uraian } \\
\hline 1. & Medan Wacana & $\begin{array}{l}\text { Realitas sosial kenaikan harga Bahan Bakar Minyak } \\
\text { bagi para kaum muda pada aspek pendidikan dan } \\
\text { kesehatan }\end{array}$ \\
\hline 2. & Penyampai Wacana & $\begin{array}{l}\text { Sifat penekanan aspek pendidikan dan kritis terhadap } \\
\text { masalah di bidang kesehatan }\end{array}$ \\
\hline 3. & Mode Wacana & $\begin{array}{l}\text { Bahasa non formal atau pasaran pada kata "Gak", } \\
\text { Huruf kapital pada "BERPENDIDIKAN" dan } \\
\text { "PENYAKITAN", Tanda seru diakhir ungkapan" }\end{array}$ \\
\hline
\end{tabular}

Berdasarkan tabel di atas ditemukan bahwa konstruksi realitas sosial kenaikan harga bahan bakar minyak ditemukan tanda dalam lirik generasi masa depan, mengarah pada lirik berikutnya "Gak Berpendidikan... Penyakitan!" masa depan yang dimaksud adalah generasi yang tidak memiliki masa depan pendidikan. Mungkin banyak generasi yang tidak sekolah pada setiap tingkatan pendidikan, mulai dari pendidikan dasar sampai perguruan tinggi. Selain generasi masa depan itu tidak bisa menikmati pendidikan, mereka juga rentan dengan penyakit, bisa saja karena mahalnya biaya perawatan kesehatan dan pengobatan. Mahalnya harga kebutuhan pokok sebagai dampak kenaikan harga menimbulkan permasalahan karena tidak bisa membagi keuangan baik untuk pendidikan maupun kesehatan. Hal ini karena tuntutan ekonomi yang semakin tinggi.

\section{BBM naik Rakyatnya jadi pada miskin ..}

Mode wacana yang dikomunikasikan dalam penggalan lirik lagu Kritis BBM; "BBM naik Rakyatnya jadi pada miskin .." dapat dilihat secara denotatif yakni naiknya harga berdampak pada rakyat miskin. Bahan bakar minyak ini sendiri terdiri dari premium, solar dan minyak tanah yang menjadi kebutuhan energi bagi rakyat. Sifat dari ungkapan ini adalah informatif kepada audien. Lirik lagu Kritis BBM mencoba mengkomunikasi kepada audien dengan cara langsung bahwa harga yang menjadi kebutuhan sehari-hari telah naik harganya. Naiknya harga ini berdampak pada rakyat miskin. Dengan komunikasi yang tegas penggalan lirik ini menyatakan adanya dampak signifikan terhadap rakyat. Sikap ungkapan lirik ini juga menekankan tujuan komunikasi pada audien agar bersikap kritis terhadap kebijakan pemerintah dalam menaikkan harga Bahan Bakar Minyak (BBM).

Mode wacana penyampaian yang digunakan dalam penggalan ungkapan ini adalah adanya kata BBM dalam bentuk singkatan agar lebih mudah dimengerti oleh audien. 
Tanda kapital pada kata "Rakyatnya" adalah menunjukkan tanda penekanan terhadap justifikasi dampak dari kenaikan harga Bahan Bakar Minyak (BBM). Sendakan imbuhan "nya" dalam kata tersebut ditujukan pada bangsa dan permasalahannya. Selain dari tanda tersebut dapat diidentifikasi pada tanda titik dua diakhir dari penggalan menunjukkan adanya kesan penekanan pada kata "miskin", maka dapat dimaknai sebagai penenkanan komunikasi dari lirik lagu Kritis BBM memberikan justifikasi adanya dampak pada rakyat miskin.Berdasarkan pembahasan di atas dapat dilihat kerangka analisis pada tabel berikut:

Tabel 2.1. Penafsiran Secara Kontekstual Pada Ungkapan "BBM Naik Rakyatnya Jadi Pada Miskin .."

\begin{tabular}{|c|l|l|}
\hline No & \multicolumn{1}{|c|}{ Kerangka Analisis } & \multicolumn{1}{|c|}{ Uraian } \\
\hline 1. & Medan Wacana & $\begin{array}{l}\text { Dampak kenaikan harga Bahan Bakar Minyak bagi } \\
\text { rakyat miskin }\end{array}$ \\
\hline 2. & Penyampai Wacana & $\begin{array}{l}\text { Sifatnya informatif, Ungkapan lirik ini juga } \\
\text { menekankan tujuan komunikasi pada audien agar } \\
\text { bersikap kritis terhadap kebijakan pemerintah dalam } \\
\text { menaikkan harga Bahan Bakar Minyak (BBM) }\end{array}$ \\
\hline 3. & Mode Wacana & $\begin{array}{l}\text { Bahasa formal, huruf kapital pada awal kata } \\
\text { "Rakyatnya", imbuhan "nya" menunjukkan bangsa } \\
\text { dan permasalahannya, dan tanda baca titik sebanyak } \\
\text { dua memberikan kesan komunikasi bersifat } \\
\text { penekanan terhadap rakyat miskin. }\end{array}$ \\
\hline
\end{tabular}

Konstruksi realitas sosial kenaikan harga Bahan Bakar Minyak (BBM) pada ungkapan ini menunjukkan secara denotatif bahwa harga Bahan Bakar Minyak (BBM) naik, tetapi rakyatnya tetap pada garis kemiskinan. Kemungkinan kenaikan Bahan Bakar Minyak (BBM) sama sekali tidak menggambarkan tujuan menarik subsidi Bahan Bakar Minyak (BBM) tidak berpengaruh dalam rangka membantu meningkatkan kesejahteraan rakyat miskin dalam semua aspek.

\section{"Kita di suruh ngirit-ngirit, DPR minta naik gaji .."}

Mode wacana dalam ungkapan lirik ini, menunjukkan tanda konotatif bahwa pemerintah secara tidak langsung menyuruh rakyatnya untuk berhemat, namun penggunaan kata berhemat digunakan kata "ngirit-ngirit". Hal ini menunjukkan hemat yang dimaksudkan adalah bahwa rakyat harus mampu menjadi hemat dan tidak boros. Namun yang muncul dalam realitas sosial ini adalah muculnya daya beli masyarakat yang menurun sehingga berdampak pada inflasi ekonomi. Pada sisi lain lirik ini juga menginformasikan bahwa Dewan Perwakilan Rakyat sebagai bagian dari pembuat kebijakan pemerintah meminta naik gaji. Maka secara denotatif ini menunjukkan kontradiksi dengan masalah rakyat miskin. Masalah pada rakyat miskin adalah hemat sedangkan tujuan dari kenaikan gaji berorientasi pada pemborosan anggaran negara yang berkonotasi bagi kepentingan pribadi para anggota Dewan Perwakilan Rakyat.

Pada tatanan sifat dari wacana ini memberi tanda adanya kesenjangan sosial akibat dari kenaikan harga Bahan Bakar Minyak (BBM) jadi audien diajak untuk berpikir secara kritis terhadap berbagai persoalan yang muncul akibat dari kenaikan harga bahan bakar minyak. Salah satu contoh yang diungkapkan lirik lagu Kritis BBM adalah DPR yang meminta kenaikan gaji padahal "Kita" (dimaknai rakyat miskin) adalah sengsara akibat dari naiknya harga bahan bakar minyak. 
Peran bahasa dalam penggalan lirik "Kita di suruh ngirit-ngirit, DPR minta naik gaji .." dapat diidentifikasi pada penggunaan huruf kapital pada kata "Kita" menunjukkan tanda yang khas dan berkonotasi pada rakyat miskin. sedangkan penggunaan bahasa non formal pada kata "ngirit-ngirit" adalah tanda kritis, karena merupakan sinonim dari kata "berhemat". Tanda koma pada akhir kata "ngirit-ngirit" menunjukkan keterangan yang tanpa ragu menjustifikasi bahwa masalah naik Bahan Bakar Minyak (BBM) berdampak besar bagi rakyat dan menerangkan bahwa adanya kejanggalan dalam masalah tersebut yakni Dewan Perwakilan Rakyat meminta naik gaji. Tanda selanjutnya yang muncul pada bagian akhir ungkapan adalah titik sebanyak dua berkonotasi makna penekanan dari masalah yang mucul pada anggota Dewan Perwakilan Rakyat. Berdasarkan pembahasan di atas dapat dilihat rangkaian konstruksi pesan yang ingin disampaikan lirik lagu Kritis BBM sebagai berikut:

Tabel 2.2. Penafsiran Secara Kontekstual Pada Ungkapan "Kita di suruh ngirit-ngirit, DPR minta naik gaji .."

\begin{tabular}{|c|l|l|}
\hline No & \multicolumn{1}{|c|}{ Kerangka Analisis } & \multicolumn{1}{c|}{ Uraian } \\
\hline 1. & Medan Wacana & $\begin{array}{l}\text { Hegemoni sosial rakyat miskin dengan kepentingan pejabat } \\
\text { legislatif }\end{array}$ \\
\hline 2. & Penyampai Wacana & $\begin{array}{l}\text { Sifatnya informatif, Ungkapan lirik ini juga menekankan } \\
\text { tujuan komunikasi pada audien agar bersikap kritis terhadap } \\
\text { masalah yang muncul seperti contoh yang diungkapkan } \\
\text { adalah DPR meminta naik gaji padahal orientasi rakyat } \\
\text { lebih penting dibandingkan masalah pribadi para anggota } \\
\text { DPR. }\end{array}$ \\
\hline 3. & Mode Wacana & $\begin{array}{l}\text { Penggunaan kata "Kita" menunjukkan makna kedekatan } \\
\text { antara lirik dengan audien (rakyat miskin), Penggunaan } \\
\text { bahasa non formal pada kata "ngirit-ngirit" merupakan } \\
\text { sinomin dari kata "hemat", dan adanya koma sebagai aspek } \\
\text { penekanan dan menerangkan adanya masalah yang muncul } \\
\text { dari dampak kenaikan harga Bahan Bakar Minyak (BBM). }\end{array}$ \\
\hline
\end{tabular}

Konstruksi realitas yang muncul pada ungkapan ini secara denotatif adalah bentuk himbauan kepada audien yakni rakyat miskin harus berhemat. Sebaliknya tuntutan kenaikan harga bahan bakar minyak untuk meningkatkan kesejahteraan rakyat miskin, malah disuruh untuk menghemat terhadap semua kebutuhan. Pada saat yang sama muncul masalah yakni Dewan Perwakilan Rakyat menuntut biaya anggaran tinggi untuk kenaikan gaji anggota Dewan Perwakilan Rakyat. Tentunya hal ini dapat dimaknai secara konotatif sangat tidak sesuai dengan himbauan, suruhan maupun perintah kepada masyarakat untuk mengirit semua kebutuhan hidup mereka.

"BBM naik Rakyat gak punya apa-apa .."

Medan wacana dalam ungkapan ini mengungkapkan bahwa realitas sosial tentang kenaikan bahan bakar minyak berdampak pada rakyat menjadi melarat. Pengungkapan realitas sosial dalam lirik ini berusaha membentuk kerangka berpikir tentang naiknya harga bahan bakar minyak adalah sesuatu yang patut dipertanyakan kepada pemerintah karena masalah yang ditimbulkannya sudah mencapai stadium yang melarat ditandai dengan konotasi "gak punya apa-apa..". Penggalan lirik ini mencoba menggiring audien agar sadar bahwa rakyat yang miskin sebenarnya sudah pada taraf melarat atau tidak punya apa-apa. Hal ini menujukkan konotasi bahwa lirik lagu Kritis BBM sudah menggiring audiensnya untuk bersikap kritis terhadap kenaikan harga. 
Pada tatanan penyampai wacana yakni lirik lagu Kritis BBM pada ungkapan "BBM naik Rakyat gak punya apa-apa .." bersikap kritis dengan gambaran sikap persuasif, tegas dan menggunakan bahasa non fomal sebagai medium dalam membangkitkan wacana kritis dalam menyikapi kenaikan harga.

Pada tatanan mode wacana dalam ungkapan lirik "BBM naik Rakyat gak punya apaapa .." ini terkandung beberapa tanda kritis yakni penggunaan bahasa non formal memberi kesan yang merakyat dalam memberi ungkapan. Karena bahasa non formal adalah bahasa yang ditujukan pada kalangan rakyat bukan pada kalangan pejabat, orang kaya, atau konglomerat yang memilki sikap formal. Penggunaan kata ini tentunya berkonotasi pada penekanan dengan tanda titik sebanyak dua pada bagian akhir ungkapan. Ini memberi kesan komunikasi tentang kemiskinan yang semakin parah diungkapkan dengan kata "gak punya apa-apa". Didasarkan pada pembahasan di atas maka, kerangka analisis dapat dirumuskan kembali dalam tabel dibawah ini:

Tabel 2.3. Penafsiran Secara Kontekstual Pada Ungkapan "BBM naik Rakyat gak punya apa-apa .."

\begin{tabular}{|c|l|l|}
\hline No & \multicolumn{1}{|c|}{ Kerangka Analisis } & \multicolumn{1}{|c|}{ Uraian } \\
\hline 1. & Medan Wacana & $\begin{array}{l}\text { Dampak kenaikan harga Bahan Bakar Minyak (BBM) } \\
\text { bagi rakyat miskin yang semakin susah }\end{array}$ \\
\hline 2. & Penyampai Wacana & $\begin{array}{l}\text { Sifatnya menggiring audiensnya untuk bersikap kritis } \\
\text { terhadap kenaikan harga Bahan Bakar Minyak } \\
(\text { BBM). }\end{array}$ \\
\hline 3. & Mode Wacana & $\begin{array}{l}\text { Penggunaan bahasa non formal pada kata "gak punya } \\
\text { apa-apa" berkonotasi pada melarat, adanya aspek } \\
\text { penekanan pada akhir dengan tanda baca titik } \\
\text { sebanyak dua berkonotasi adanya masalah } \\
\text { kemiskinan dan kemelaratan pada rakyat. }\end{array}$ \\
\hline
\end{tabular}

Konstruksi realitas sosial kenaikan harga bahan bakar minyak melalui ungkapan lirik lagu "BBM naik Rakyat gak punya apa-apa .." berkonotasi pada dampak kenaikan harga bahan bakar minyak berakibat terbalik sesuai dengan tujuan pemerintah meningkatkan kesejahteraan rakyat miskin. Namun, malah sebaliknya rakyat tidak punya apa-apa artinya sudah mencapai taraf kehidupan yang melarat.

\section{"Diminta hidup sederhana .."}

Mode wacana yang diungkapakan dalam ungkapan lirik lagu ini adalah salah satu bentuk permintaan, jika dilihat pemaknaan secara bahasa. Kata "Diminta" dapat juga dimaknai dengan memohon atau dimohon. Namun secara halus, konotasi dari bahasa ini memaksa rakyat untuk hidup sederhana, sebab dampak kenaikan harga bahan bakar minyak secara terpaksa harus menjalani hidup secara sederhana dengan berhemat sebagaimana pada ungkapan sebelumnya (kata "ngirit-ngirit"). "Hidup sederhana" itu juga dapat dikonotasikan pada rakyat yang sudah mapan kehidupannya, namun jika dikonotasikan pada rakyat miskin berarti maknanya menyuruh atau memaksa rakyat untuk menjadi melarat. Sebab sudah tidak mampu harus lebih menghemat lagi, jadi apa yang menjadi kebutuhan harus ditekankan biayanya, hal ini tentunya menjadikan rakyat miskin menjadi menderita. Jadi mode wacana dalam lirik ini berusaha mengungkap realitas sosial dampak kenaikan harga bahan bakar minyak pada rakyat untuk sadar bahwa hidup sederhana adalah jalan paksaan dari pemerintah melalui kebijakannya.

Sifat dari lirik ini dalam kerangka analisis penyampai wacana adalah bersifat kritis secara halus terhadap realitas yang ada pada rakyat miskin atau konglomerat. Konotasi dari 
hidup sederhana merupakan umum dalam pemaknaan terhadap ukuran kesanggupan individu sesuai dengan penghasilannya. Maka konsep hidup sederhana pada rakyat yang mapan mungkin bisa namun pada rakyat miskin dimaknai sebagai suatu pemaksanaan secara halus dengan kata lain adalah hegemoni pemerintah dalam mencintrakan konsep hidup sederhana adalah bentuk solusi dari dampak kenaikan harga bahan bakar minyak.

Mode wacana yang digunakan adalah bahasa formal dengan ungkapan "diminta" dengan sinonim "dimohon". Pada penggunaan ungkapan "hidup sederhana" berkonotasi pada dua pemaknaan secara sosial adalah pada rakyat mapan dan rakyat miskin. Kemudian pada akhir ungkapan ditujukan aspek penekanan dengan tanda baca titik sebanyak dua. Ini berkonotasi adanya unsur pemaksaan secara halus bahwa jalan hidup sederhana adalah jalan yang wajib ditempuh akibat dari dampak kenaikan harga bahan bakar minyak. Berdasarkan pembahasan di atas, dapat dirumuskan konstruksi realitas sosial kenaikan harga memiliki kerangka tabel berikut ini:

Tabel 2.4. Penafsiran Secara Kontekstual Pada Ungkapan "Diminta hidup sederhana .."

\begin{tabular}{|c|l|l|}
\hline No & \multicolumn{1}{|c|}{ Kerangka Analisis } & \multicolumn{1}{|c|}{ Uraian } \\
\hline 1. & Medan Wacana & $\begin{array}{l}\text { Hegemoni dan tuntutan pemerintah terhadap } \\
\text { rakyat untuk hidup sederhana secara halus. }\end{array}$ \\
\hline 2. & Penyampai Wacana & $\begin{array}{l}\text { Sifatnya adalah konstruktif yang berkonotasi } \\
\text { pada unsur paksaan secara halus melalui } \\
\text { penetapan kenaikan harga Bahan Bakar } \\
\text { Minyak (BBM). }\end{array}$ \\
\hline 3. & Mode Wacana & $\begin{array}{l}\text { Penggunaan bahasa formal pada kata } \\
\text { "Diminta hidup sederhana" berkonotasi pada } \\
\text { unsur pemaksaan melalui peraturan. Tanda } \\
\text { baca titik sebanyak dua menunjukkan } \\
\text { adanya aspek penekanan terhadap konsep } \\
\text { hidup sederhana. }\end{array}$ \\
\hline
\end{tabular}

Konstruksi realitas sosial kenaikan harga pada lirik lagu "Diminta hidup sederhana" merupakan tanda konotatif bahwa kebijakan pemerintah adalah bersifat memaksa kepada rakyat utamanya rakyat yang miskin. Tujuan komunikasi melalui penggalan lirik lagu ini menunjukkan adanya unsur paksaan sehingga konstruksi ini merupakan bentuk dialektika lirik lagu Kritis BBM dalam menginterpretasikan pemaksaan bagi rakyat miskin.

"Para Pejabat foya-foya .. oya .. AHA !"

Medan wacana dalam ungkapan ini menunjukkan realitas sosial ketika naiknya harga Bahan Bakar Minyak (BBM) yang ditujukan secara denotatif menyebut pejabat. Namun kata "pejabat" lebih ditujukan pada pejabat legislatif atau DPR (dikonotasikan pada ungkapan lirik sebelumnya) yang membuat legalisasi kenaikan harga. Para pejabat yang dimaksud pada ungkapan lirik ini adalah menerangkan sikap pejabat yang tidak pro kepada rakyat miskin dan memperkaya diri sendiri dengan jalan yang tidak wajar. Karena ketidakwajaran ini hingga menimbulkan tanda tanya besar bagi masyarakat dengan gaya hidup mewah para pejabat tersebut. 
Kemewahan para pejabat atau Dewan Perwakilan Rakyat dalam ungkapan "Para Pejabat foya-foya.." menjadi tanda secara denotatif kesan dari ungkapan ini kemewahan merupakan bentuk foya-foya. Berfoya-foya itu sendiri diartikan dengan menghamburkan uang untuk tujuan bersenang-senang. Jadi kesan komunikasi dari penggunaan "foya-foya" dalam lirik tersebut menunjukkan secara denotatif bahwa pejabat telah menghamburkan uang negara secara tidak sah untuk kepentingan pribadi. Sebagaimana sifat ungkapan lirik ini adalah bersifat eksplisit dan infomatif mengemukan rahasia umum tentang citra para pejabat yang korupsi.

Melihat tanda melalui mode wacana dalam ungkapan lirik "Para Pejabat foyafoya..oya..AHA !" terkandung beberapa tanda yakni penggunaan huruf kapital "Pejabat", seharusnya secara bahasa tulisan dimulai dengan huruf kapital namun terdapat ditengah kalimat. Ini menunjukkan sifat pelabelan terhadap kata tersebut memiliki pensifatan yang khusus, sifat tersebut adalah "foya-foya". Kemudian dari sifat tersebut ada penggunaan titik sebanyak dua, menunjukkan tanda penekanan, sehingga memberikan kesan bahwa sifat dari "Pejabat" tersebut benar adanya. Penguatan ini juga terdapat setelah kata "oya" terdapat titik sebanyak dua. Kata "AHA" dengan seruan menujukkan kesan emosional ketidaksetujuan terhadap sikap pejabat yang berfoya-foya.

Berdasarkan pada tanda-tanda yang diungkapkan di atas, maka dapat disimpulkan dalam kerangka analisis pada tabel berikut ini

Tabel 2.5. Penafsiran Secara Kontekstual Pada Ungkapan "Para Pejabat foya-foya .. oya .. AHA !"

\begin{tabular}{|c|l|l|}
\hline No & \multicolumn{1}{|c|}{ Kerangka Analisis } & \multicolumn{1}{c|}{ Uraian } \\
\hline 1. & Medan Wacana & $\begin{array}{l}\text { Sikap para pejabat legislatif atau DPR yang } \\
\text { banyak menghamburkan uang negara } \\
\text { dengan tujuan kepentingan pribadi }\end{array}$ \\
\hline 2. & Penyampai Wacana & $\begin{array}{l}\text { Sifat infomatif dan eksplisit mengungkap } \\
\text { sikap para pejabat yang berfoya-foya. }\end{array}$ \\
\hline 3. & Mode Wacana & $\begin{array}{l}\text { Penggunaan huruf kapital pada kata Pejabat } \\
\text { memberi kesan istimewa dalam sifatnya, } \\
\text { sifatnya berdenotasi pada "berfoya-foya", } \\
\text { adanya titik yang memberikan tanda } \\
\text { penekanan sifat tersebut, ditambah dengan } \\
\text { ungkapan "oya...AHA! Menandakan secara } \\
\text { denotatif kata-kata yang emosional ketidak } \\
\text { setujuan terhadap sikap para pejabat. }\end{array}$ \\
\hline
\end{tabular}

Pada tabel di atas menunjukkan adanya tanda-tanda secara denotatif pada ungkapan lirik lagu "Para Pejabat foya-foya .. oya .. AHA!" memberikan kritis terhadap para pejabat dengan sikap mereka ketika stuasi perekonomian rakyat yang menderita akibat dari kenaikan harga Bahan Bakar Minyak. Ini merupakan suatu bentuk kesenjangan dalam menjalankan roda pemerintahan yang tidak pro kepada rakyat miskin.

Secara tegas lirik lagu ini mengungkapkan konstruksi realitas sosial yang muncul pada gaya hidup kalangan pejabat pemerintah yang cenderung menunjukkan sikap yang tidak perduli dengan kondisi rakyat miskin yang menderita. Kata "Pejabat" dari lirik ini dikonotasikan pemaknaannya pada ungkapan lirik lagu sebelumnya dengan penyebutan "DPR minta naik gaji”. 


\section{"BBM naik hidup penuh tanda tanya?"}

Ungkapan lirik ini berusaha mengungkapkan konstruksi sosial dari dampak kenaikan harga bahan bakar minyak dengan wacana ketidaktentuan dan keraguan rakyat akan kebijakan pemerintah dalam mensejahterakan rakyat. Kesimpangsiuran wacana tentang kenapa harga naik dan apa penyebabnya? sehingga menuai berbagai dilema di kalangan rakyat miskin karena dampaknya mengakibatkan naiknya harga kebutuhan sandang, pangan dan sebagainya. Konstruksi dari pesan dalam lirik ini secara konotatif adanya kebijakan pemerintah yang tidak transparan terhadap rencana mensejahterakan rakyat miskin.

Sifat dari lirik ini mencoba mengungkap dilema rakyat miskin akan dampak dari kenaikan harga. Hal merupakan tanda dari ungkapan lirik lagu ini menjadi suatu konstruksi realitas sosial yang memberikan kesan adanya keraguan dan ketidakpastian penanggulangan masalah ekonomi yang semakin memburuk. Pemaknaan ini dikuatkan dengan ungkapan lirik sebelumnya "BBM naik Rakyatnya jadi pada miskin .. Kita di suruh ngirit-ngirit, DPR minta naik gaji .. BBM naik Rakyat gak punya apa-apa ..Diminta hidup sederhana .. Para Pejabat foya-foya .. oya .. AHA !“. Rangkaian lirik ini menunjukkan bentuk-bentuk tanda-tanda konotatif adanya kondisi psikologis pada rakyat miskin terhadap undang-undang sebagai landasan pemerintah menentukan kebijakan dan menjalankan roda pemerintahan yang mensejahterakan rakyat.

Berdasarkan pembahasan di atas, dapat dilihat sistematika konstruksi realitas sosial dampak kenaikan harga bahan bakar minyak dapat dilihat pada tabel berikut ini:

Tabel. 3.1. Penafsiran Secara Kontekstual Pada Ungkapan "BBM naik hidup penuh tanda tanya?"

\begin{tabular}{|c|l|l|}
\hline No & \multicolumn{1}{|c|}{ Kerangka Analisis } & \multicolumn{1}{|c|}{ Uraian } \\
\hline 1. & Medan Wacana & $\begin{array}{l}\text { Keraguan pada rakyat miskin terhadap ketidakpastian } \\
\text { pemerintah dalam kebijakan mensejahterakan } \\
\text { pemerintah }\end{array}$ \\
\hline 2. & Penyampai Wacana & $\begin{array}{l}\text { Sifatnya informatif dalam mengungkapkan wacana } \\
\text { keraguan terhadap kesejahteraan hidup masyarakat } \\
\text { miskin. }\end{array}$ \\
\hline 3. & Mode Wacana & $\begin{array}{l}\text { Penggunaan bahasa yang sederhana namun } \\
\text { memberikan makna yang persuasif. Penggunaan } \\
\text { tanda tanya menunjukkan tanda keraguan akan } \\
\text { kinerja pemerintah yang tidak pro kepada rakyat. }\end{array}$ \\
\hline
\end{tabular}

Berdasarkan tabel di atas, secara denotatif ungkapan lirik lagu "BBM naik hidup penuh tanda tanya?" menunjukkan sifat dari lirik ini yang kritis terhadap kebijakan pemerintah yang tidak pro kepada kesejahteraan rakyat. Meskipun bentuk pertanyaan yang ditampilkan dalam lirik ini, secara konotatif dapat dilihat tanda bahwa tujuan komunikasinya adalah mendeskripsikan berbagai persoalan hidup yang muncul akibat dari dampak kenaikan harga. Salah satu dampak yang real adalah naiknya harga bahan pangan, sandang, jasa dan pelayanan. Hal ini menjadikan rakyat yang hidup dalam garis kemiskinan menjadi menderita. Ketidakjelasan inilah menuai keraguan pada rakyat akan kinerja pemerintah dalam membuat anggaran APBN yang mensejahterakan rakyat.

\section{"Kelebihan dananya kemana?"}

Medan wacana yang muncul pada ungkapan ini merupakan bentuk rangkaian masalah yang muncul dari ketidakpastian hidup bagi rakyat, hingga pada akhirnya rakyat harus bicara secara kritis terkait kebijakan pemerintah dalam mensejahterakan kehidupan 
rakyat miskin. Sebab dana subsidi jelasnya harus dialokasikan pemerintah untuk memberdayakan rakyat secara bijaksana. Dana subsidi tidak sedikit, dapat mencapai triliyunan, maka secara jelas lirik ini memberikan pertanyaan; kemana dialokasikan dana subsidi tersebut?.

Sifat dari lirik ini menandakan secara denotatif mempertanyakan kebijakan anggaran pemerintah harus transpransi yang jelas mengenai pengalokasian dana subsidi, sehingga. tujuan komunikasi dari lirik ini mencoba menggambarkan betapa audien harus kritis dan mawas terhadap kebijakan pemerintah agar tidak terjadi penyelewangan dana yang merugikan kepentingan rakyat. Oleh karena itu kesan pertanyaan dari lirik ini adalah tegas dan transpran.

Mode wacana yang dipakai dalam penyampaian kesan kritis tegas dan transparan ditandai dengan bahasa yang jelas dimengeti. Konotasi imbuhan "nya" pada kata "dananya" menunjukkan dana subsidi yang tarik pemerintah. Penggunaan tanda tanya pada akhir ungkapan lirik "Kelebihan dananya kemana? Merupakan bentuk kritis agar wacana kritis bagi khalayak untuk menuntut pemerintah agar lebih transparan dengan pengelolaan dana anggaran APBN. Berdasarkan pembahasan terhadap penggalan lirik lagu Kritis BBM di atas dapat disintesiskan melalui tabel berikut ini:

Tabel 3.4. Tabel Penafsiran Secara Kontekstual Pada Ungkapan "Kelebihan dananya kemana?"

\begin{tabular}{|c|l|l|}
\hline No & \multicolumn{1}{|c|}{ Kerangka Analisis } & \multicolumn{1}{|c|}{ Uraian } \\
\hline 1. & Medan Wacana & $\begin{array}{l}\text { Mempertanyakan kebijakan pemerintah dalam } \\
\text { mengelola dan tranparansi alokasi dana subsidi Bahan } \\
\text { Bakar Minyak (BBM) }\end{array}$ \\
\hline 2. & Penyampai Wacana & $\begin{array}{l}\text { Sifat dari lirik ini menggugah audiens untuk tetap } \\
\text { mengawasi dan kritis terhadap berbagai kebijakan } \\
\text { pemerintah yang tidak pro kepada rakyat. }\end{array}$ \\
\hline 3. & Mode Wacana & $\begin{array}{l}\text { Penggunaan bahasa yang formal dan sederhana } \\
\text { menjadi tanda komunikasi yang jelas tegas dan kritis, } \\
\text { dikuatkan dengan tanda tanya pada akhir menujukkan } \\
\text { betapa pentingnya peran rakyat dalam mengawasi dan } \\
\text { kritis sehingga pemerintah dituntut transparan. }\end{array}$ \\
\hline
\end{tabular}

Berdasarkan tabel di atas, secara denotatif lirik lagu "Kelebihan dananya kemana? Menjadi sebuah tanda konstruksi realitas sosial dampak kenaikan harga Bahan Bakar Minyak (BBM), sebab pemerintah menarik dana subsidinya. Kebijakan ini mengakibatkan naiknya harga kebutuhan primer dan skunder bagi rakyat, terutama rakyat miskin. Maka secara konotatif lirik ini mencoba mengajak khalayak untuk bersikap kritis, tegas, lugas dan mengawasi pemerintah agar tidak terjadi korupsi di kalangan pejabat pemerintah.

\section{"BBM naik Kepanikan di mana-mana ! panik di POM-POM Bensin, Panik orang menuntut dana kompensasi .."}

Pada lirik ini mengkomunikasikan tentang realitas sosial dampak kenaikan harga bahan bakar minyak kepada rakyat miskin secara langsung. Istilah "Panik" sebagai tanda yang menunjukkan denotasi dari peristiwa di beberapa tempat. Kata "panik" dimaknai sebagai bentuk dari kondisi psikologis manusia terhadap masalah yang ada. Pada kamus Bahasa Indonesia diartikan bingung, gugup, dan takut secara mendadak. Hal ini 
menujukkan bahwa dampak langsung dari kenaikan harga telah memiliki dampak psikologis dan mengguncang stabilitas sosial, khususnya bagi rakyat miskin.

Selain itu, lirik ini juga mengungkapkan jawaban dari pertanyan pada lirik "BBM naik hidup penuh tanda tanya? Kelebihan dananya kemana?". Jawaban dari kedua pertanyaan ini telah disebutkan yakni "panik" atau "kepanikan" dan "dana kompensasi". Dana kompensasi ini merupakan salah satu program pemerintah dalam mengatasi berbagai kepanikan rakyat dengan naiknya harga. Dana kompensasi ini merupakan bantuan langsung bagi masyarakat yang tidak mampu dengan pencairan dana secara bertahap. Namun tidak lepas dari terjadi juga berbagai kepanikan atau kebingungan serta permasalahan mengenai tuntutan dana kompesasi Bahan Bakar Minyak (BBM) sebagaimana salah satu contohnya diceritakan dalam lirik lagu Kritis BBM.

Penyampaian wacana realitas sosial dampak kenaikan harga pada lirik ini bersifat informatif subtansial. Maksudnya secara umum yang paling banyak mendapat sorotan di publik dan media massa adalah masalah dana kompensasi sebagai jaminan kesejahteraan rakyat miskin. Namun tidak tertutup kemungkinan, kebingungan dan dilema rakyat miskin masih banyak sebagaimana konotasi dari ungkapan lirik "BBM naik Kepanikan di manamana !". Kata "dimana-mana" dalam kamus Bahasa Indonesia artinya di segala tempat, jadi permasalahan tentang bahan bakar minyak memiliki cakupan permasalahan yang luas tidak hanya pada pom bensin. Oleh karena itu kesan dari lirik ini adalah merupakan konstruktif informatif terhadap apa saja yang berpotensi menyebabkan berbagai permasalahan itu muncul dalam berbagai aspek kehidupan. Berdasarkan pembahasan ini, dapat disintesiskan dalam bentuk tabel berikut ini:

Tabel. 3.5. Penafsiran Secara Kontekstual Pada Ungkapan

“ "BBM naik Kepanikan di mana-mana ! panik di POM-POM Bensin, Panik orang menuntut dana kompensasi ..”

\begin{tabular}{|c|l|l|}
\hline No & \multicolumn{1}{|c|}{ Kerangka Analisis } & \multicolumn{1}{|c|}{ Uraian } \\
\hline 1. & Medan Wacana & $\begin{array}{l}\text { Membicarakan tentang ruang lingkup permasalahan } \\
\text { dari dampak kenaikan harga Bahan Bakar Minyak } \\
(\text { BBM }) \text { terhadap rakyat miskin. Contoh beberapa } \\
\text { permasalahan pada beberapa tempat yakni pom } \\
\text { bensin dan masalah dana kompensasi. }\end{array}$ \\
\hline 2. & Penyampai Wacana & $\begin{array}{l}\text { Sifat dari lirik ini adalah memberitakan tentang } \\
\text { realitas sosial berdasarkan kondisi psikologis rakyat } \\
\text { miskin yang dimana kondisi tersebut disebut "panik". } \\
\text { Lirik ini juga menjelaskan secara denotatif bahwa } \\
\text { masalah Bahan Bakar Minyak (BBM) memiliki ruang } \\
\text { lingkup masalah yang luas karena menyangkut } \\
\text { permasalahan khalayak ramai. }\end{array}$ \\
\hline 3. & Mode Wacana & $\begin{array}{l}\text { Penggunaan tanda kutip pada awal kalimat } \\
\text { menunjukkan bahwa masalah Bahan Bakar Minyak } \\
\text { adalah masalah yang berpotensi besar, dikuatkan } \\
\text { dengan tanda titik pada akhir kalimat pada lirik ini, } \\
\text { tetapi tidak dengan tanda kutip penutup. }\end{array}$ \\
\hline
\end{tabular}

Berdasarkan tabel di atas, bahwa lirik " "BBM naik Kepanikan di mana-mana ! panik di POM-POM Bensin, Panik orang menuntut dana kompensasi ..." secara denotatif menunjukkan tanda bahwa masalah bahan bakar minyak adalah masalah yang besar bagi pemerintah dalam mensejahterakan rakyat miskin. Melalui lirik ini juga dapat dianalisa secara konotatif mengandung makna bahwa konteks permasalahan ini masih berkelanjutan 
di masa depan, karena ketergantungan terhadapnya. Untuk itu permasalahan yang diungkapkan lirik lagu Kritis BBM bukanlah suatu yang bersifat insidentil saja, malah merupakan ramalan permasalahan tentang masa depan kesejahteraan rakyat, kesahatan, dan pendidikan bagi rakyat miskin di masa depan. Bagaimana pemerintah mengatasi permasalahan tersebut? Tentunya tergantung dari stuasi politik, ekonomi dan kebijakan dari pemerintah itu sendiri.

Penekanan permasalahan pada lirik lagu ini juga menunjukkan adanya konstruksi realitas sosial dampak kenaikan harga masih terus berdampak karena secara global, sumber energi yang berasal dari minyak bumi terus-menerus dioptimalkan akan terus berkurang. Berkurangnya sumber energi yang berasal dari minyak bumi tersebut akan menjadi dampak permasalahan yang besar khususnya bagi rakyat yang tergantung padanya.

\section{Cerita Di Balik Kecurangan Alokasi Bantuan Dana Kompensasi}

Tapi ada 1 cerita ni tentang dana kompensasi ... seseorang bernama AHMAD SALEH mendatangi pak RT"

Ahmad Saleh; "Pak .. saya ingin menukar kupon dana kompensasi saya"

Pak RT; "Atas nama?!?"

Ahmad Saleh;"AHMAD SALEH .. pak !"

Pak RT; "Oh, ini sudah diambil oleh Bpk. AHMAD SOLEH .."

Ahmad Saleh; "LOH?? Saya AHMAD SALEH,"

Pak RT; "Tapi ini dananya sudah tidak ada !!"

Ahmad Saleh; "Loh, Pak RT gimana sih !?? saya SALEH pak Bukan SOLEH !!"

Pak RT; "Yah, tp udah tidak ada dananya, gimana donk!?"

Ahmad Saleh; "WAH Bpk gak bertanggung jawab donk? Bapak payah nih,,, Bpk.

KURANG AJAR !!!

Rangkaian lirik di atas, merupakan rangkaian sebuah cerita singkat dalam lirik lagu

Kritis BBM. Sebagaimana sebuah cerita memiliki rangkaian informasi yang memiliki pesan komunikasi yang denotatif dan konotatif di dalamnya. Cerita singkat ini berada pada bagian akhir dari lirik lagu Kritis BBM. Rangkaian liriknya mengisahkan tentang Ahmad Saleh yang menuntut dana kompensasi Bahan Bakar Minyak (BBM) kepada Pak RT melalui tanda kupon yang dibagikan kepada warga yang berhak mendapatkannya.

Penempatan posisi tokoh Ahmad Saleh pada kisah ini adalah sebagai warga miskin yang berhak mendapat dana kompensasi. Melihat tanda denotasi pada cerita ini secara umum menunjukkan kepada audien betapa tokoh Ahmad Saleh yang menuntut haknya kepada Pak RT tidak sesuai dengan yang diharapkannya. Secara denotatif kisah ini menujukkan adanya kecurangan dalam ranah tatanan masyarakat kecil tentang pembagian dana kompensasi. Hal ini dapat dilihat bahwa Pak RT telah memberikan dana kompensasi yang tidak tepat pada sasarannya sebagaimana lirik berikut:

AHMAD SALEH mendatangi pak RT"

Ahmad Saleh; "Pak .. saya ingin menukar kupon dana kompensasi saya"

Pak RT; "Atas nama?!?"

Ahmad Saleh;"AHMAD SALEH .. pak ! "

Pak RT; "Oh, ini sudah diambil oleh Bpk. AHMAD SOLEH .."

Ahmad Saleh; "LOH?? Saya AHMAD SALEH,"

Pak RT; "Tapi ini dananya sudah tidak ada !!"

Ahmad Saleh; "Loh, Pak RT gimana sih !?? saya SALEH pak Bukan SOLEH !!" 
Lirik ini menginformasikan adanya tanda bahwa penyaluran dana kompensasi yang tidak tepat sasaran. Jika melihat tanda konotasi dari perbedaan nama penerima dana kompensasi antara "Saleh" dengan "Soleh" yang menjadi kekeliruan Pak RT merupakan bentuk tanda yang nyata tidak tepat sasaran, merupakan bentuk kritis lirik ini secara umum kepada para pejabat dari tingkat atas hingga tingkat rendah.

Selain itu, cerita dalam lirik lagu Kritis BBM tersebut, mengungkapkan adanya tindak korupsi, dimulai dari kalangan pejabat tinggi hingga pejabat rendah seperti Pak RT yang memimpin wilayah kelurahan. Jadi konotasi cerita ini pada kutipan lirik lagu ini mengungkap realitas sosial dari dampak kenaikan harga Bahan Bakar Minyak (BBM) amat potensial terjadi tindak pidana korupsi, khususnya penyewengan dana kompensasi sebagai bentuk program mensejahterakan rakyat miskin. Memang pada lirik ini secara denotatif tidak disebutkan bagaimana cara korupsi yang dilaksanakan Pak RT terhadap warganya yang bernama Ahmad Saleh. Gambaran korupsi pada lirik ini hanya berbentuk klise yang tidak disebutkan secara denotatif, namun bermakna konotasi terjadi korupsi dengan dalih kesalahan pada daftar penerima bantuan dana kompensasi. Hal ini dibuktikan bahwa kehadiran Ahmad Saleh membawa bukti kupon penerima yang berhak. tetapi ada kecuarangan dalam pendataan rakyat yang berhak dan yang tidak berhak mendapat bantuan dana kompensasi.

Pada kelanjutan cerita dalam lirik ini mengungkapkan bentuk kepanikan rakyat miskin yang menuntut dana kompensasi kepada pemerintah di sebutkan dalam lirik; "Pak RT; "Yah, tp udah tidak ada dananya, gimana donk!?" Ahmad Saleh; "WAH Bpk gak bertanggung jawab donk? Bapak payah nih,,, Bpk. KURANG AJAR !!!” tanda denotatif kepanikan rakyat karena ulah pejabat yang korupsi menyebabkan timbul pelabelan yang anarki yakni "Bpk. KURANG AJAR !!!" ini berkonotasi pada sikap pejabat yang menunjukkan betapa citra moral pejabat sangat buruk di mata rakyat.

Tabel 4.1. Penafsiran Secara Kontekstual Pada Cerita dalam Lirik Lagu Kritis BBM Karya Slank

\begin{tabular}{|c|l|l|}
\hline No & \multicolumn{1}{|c|}{ Kerangka Analisis } & \multicolumn{1}{c|}{ Uraian } \\
\hline 1. & Medan Wacana & $\begin{array}{l}\text { Tema yang diungkap dalam cerita ini adalah realitas } \\
\text { sosial dampak dari kenaikan harga Bahan Bakar } \\
\text { Minyak (BBM) terkait dana kompensasi. Lirik ini } \\
\text { menceritakan sebuah bentuk kejadian kecil tentang } \\
\text { kesalahan dari penerima dana kompensasi, namun } \\
\text { pada dasarnya ini adalah suatu realitas yang benar ada } \\
\text { di kalangan rakyat miskin. }\end{array}$ \\
\hline 2. & Penyampai Wacana & $\begin{array}{l}\text { Wacana yang muncul dalam cerita ini mencoba } \\
\text { mengangkat berbagai bentuk realitas dari masalah } \\
\text { penyaluran dari dana kompensasi sebagai bentuk } \\
\text { dana untuk kesejahteraan rakyat. }\end{array}$ \\
\hline 3. & Mode Wacana & $\begin{array}{l}\text { Mode dalam lirik ini adalah cerita singkat dan padat. } \\
\text { Alur cerita menunjukkan secara nyata tentang } \\
\text { percakapan yang berkonotasi pada kesan adanya } \\
\text { kecurangan. Latar setting cerita merupakan bentuk } \\
\text { klise dari realitas kecurangan di tidak hanya pada } \\
\text { pejabat tinggi tetapi juga dapat terjadi pada tingkat } \\
\text { pejabat desa. }\end{array}$ \\
\hline
\end{tabular}


Konstruksi realitas sosial dalam ungkapan cerita dalam lirik lagu Kritis BBM mencitrakan pejabat kalangan rendah bisa korupsi dan penyaluran bantuan tidak tepat pada sasaran. Jadi kesan dari dana kompensasi yang pada dasarnya adalah kebijakan pemerintah yang insidentil tersebut telah membuat kepanikan bagi rakyat miskin, karena sibuk dengan bantuan dari pemerintah.

Berdasarkan pembahasan di atas dapat sintesiskan bahwa konstruksi relitas sosial dampak kenaikan harga Bahan Bakar Minyak dalam lirik lagu Kritis BBM karya Slank adalah jenis konstruksi realisme hipotesis. Realisme hipotesis dalam lirik tersebut berupa informasi tentang dampak dari kenaikan harga Bahan Bakar Minyak kepada rakyat. Hal ini dibuktikan dengan adanya hasil semiotika berupa pengetahuan dalam lirik lagu Kritis BBM sebagai berikut

Tabel 4.2. Konstruksi Realisme Hipotesis pada Lirik Lagu Kritis BBM Karya Slank

\begin{tabular}{|c|c|c|}
\hline No & Hasil Semiotika & Pengetahuan yang Terkandung \\
\hline 1. & Regenerasi Masa Depan & $\begin{array}{l}\text { Adanya masalah sosial yang berkelanjutan, maka generasi } \\
\text { muda (masa depan) harus sadar akan permasalahan } \\
\text { tersebut sebagai masalah yang harus dipecahkan. }\end{array}$ \\
\hline 2. & $\begin{array}{l}\text { Masa Depan Pendidikan dan } \\
\text { Kesehatan }\end{array}$ & $\begin{array}{l}\text { Aspek pendidikan dan kesehatan merupakan masalah } \\
\text { bangsa yang harus dipecahkan generasi selanjutnya }\end{array}$ \\
\hline 3. & $\begin{array}{l}\text { Kurangnya Kesejahteraan } \\
\text { pada Rakyat Miskin }\end{array}$ & $\begin{array}{l}\text { Kesejahteraan rakyat yang tidak meningkat akibat dari } \\
\text { masalah ekonomi }\end{array}$ \\
\hline 4. & $\begin{array}{l}\text { Hegemoni Sosial pada Rakyat } \\
\text { Miskin Versus Legislatif }\end{array}$ & $\begin{array}{l}\text { Kesenjangan sosial antara pejabat legislatif dengan rakyat } \\
\text { miskin yang pada hakikatnya legislatif adalah bagian dari } \\
\text { rakyat itu sendiri }\end{array}$ \\
\hline 5. & $\begin{array}{l}\text { Taraf Hidup Rakyat Miskin } \\
\text { Semakin Susah }\end{array}$ & $\begin{array}{l}\text { Kondisi buruknya ekonomi berdampak turunnya kualitas } \\
\text { kesejahteraan rakyat dalam tatanan sosial ekonomi. }\end{array}$ \\
\hline 6. & $\begin{array}{l}\text { Hegemoni Sosial Rakyat } \\
\text { Miskin dengan Konsep Hidup } \\
\text { Sederhana }\end{array}$ & $\begin{array}{l}\text { Gambaran konsep hidup sederhana sebagai strategi } \\
\text { pemerintah dalam mencapai tujuan birokrasi yang pada } \\
\text { hakikatnya menyengsarakan rakyat }\end{array}$ \\
\hline 7. & $\begin{array}{l}\text { Rakyat Menderita Pejabat } \\
\text { Memperkaya Diri }\end{array}$ & $\begin{array}{l}\text { Kepemimpinan yang tidak mendahulukan kepentingan } \\
\text { rakyat }\end{array}$ \\
\hline 8. & $\begin{array}{l}\text { Kebijakan Pemerintah Tidak } \\
\text { Transparan }\end{array}$ & Indikasi korupsi dan penyelewangan \\
\hline 9. & $\begin{array}{l}\text { Tuntutan Rakyat Terhadap } \\
\text { Tranparansi Pemerintah }\end{array}$ & $\begin{array}{l}\text { Respon sosial dari masyarakat terhadap ketidakadilan } \\
\text { (balance) pemerintah }\end{array}$ \\
\hline 10. & $\begin{array}{l}\text { Citra Buruk PERTAMINA } \\
\text { Sebagai Ladang Korupsi }\end{array}$ & $\begin{array}{l}\text { Persepsi, pandangan, dan pendapat rakyat terhadap } \\
\text { pengelolaan aset negara untuk kepentingan rakyat }\end{array}$ \\
\hline 11. & $\begin{array}{l}\text { Goncangan Stabilitas Sosial } \\
\text { bagi Rakyat Miskin }\end{array}$ & $\begin{array}{l}\text { Keadaan sosial yang tidak terkontrol dan tidak sehat akibat } \\
\text { dari dampak kenaikan harga Bahan Bakar Minyak (BBM) }\end{array}$ \\
\hline 12. & $\begin{array}{l}\text { Cerita Dibalik Kecurangan } \\
\text { Alokasi Bantuan Dana } \\
\text { Kompensasi }\end{array}$ & $\begin{array}{l}\text { Proses kecurangan dan penyelewengan potensial pada } \\
\text { jalannya pembangunan nasional, utamanya peningkatan } \\
\text { kesejahteraan rakyat. }\end{array}$ \\
\hline
\end{tabular}

Berdasarkan tabel di atas, bahwa pengetahuan yang terkandung dalam lirik lagu Kritis BBM karya Slank adalah bersifat konstruktif dalam menjabarkan realitas sosial. Sebagaimana hasil dari semiotika dimaknai sebagai suatu bentuk konstruksi yang relevan hingga saat ini. Inilah yang menyakinkan peneliti adanya pesan konstruktif dalam lirik tersebut memiliki kedalaman makna yang tinggi. Oleh karena itu peneliti menyimpulkan bahwa pesan komunikasi dalam lirik tersebut adalah realitas sosial.

Selain sebagai pesan konstruktif dalam muatan-muatan lirik lagu Kritis BBM, pengkajian semiotika komunikasi juga menempatkan realitas sosial memiliki tujuan. 
Tujuan komunikasi dalam lirik lagu Kritis $B B M$ pada dasarnya dengan mengalisa intensitas, sistematika dan bagaimana teks ditulis agar mudah dimengerti oleh audiensnya. Oleh karena itu suatu pesan komunikasi memiliki tujuan di dalamnya, pada pembahasan ini peneliti menganalisa rangkaian pembahasan lirik lagu Kritis BBM dalam kerangka pesan tentang konstruksi realitas sosial dampak kenaikan harga Bahan Bakar Minyak (BBM) dalam lirik lagu Kritis $B B M$ dengan sudut pandang analisa tujuan dari pesan komunikasi.

1. Mengubah pendapat

Lagu Kritis BBM karya Slank merupakan bentuk karya yang memang di dalam lirik lagu tersebut memiliki makna yang dapat diinterpretasikan sebagai karya yang dikomunikasikan untuk merubah pendapat audiensnya. Hal ini karena di dalam lirik lagu itu sendiri, setelah diteliti memiliki konstruksi pesan yang berkaitan dengan tema realitas sosial kenaikan harga Bahan Bakar Minyak (BBM). Sesuai dengan tanda dalam lirik lagu Kritis BBM yang disebutkan Slank melalui lirik lagu Kritis BBM berupaya memberikan informasi tentang dampak kenaikan harga Bahan Bakar Minyak (BBM) terhadap realitas pendidikan, kesehatan dan kesejahteraan rakyat miskin.

Pembuktian dari informasi ini dapat dilihat pada tabel berikut ini:

Tabel 4.3. Nilai Informatif dalam Lirik Lagu Kritis BBM dengan Tujuan Komunikasi untuk Merubah Pendapat Audiens

\begin{tabular}{|c|c|c|c|}
\hline Analisa & Rangkaian Lirik & Tanda dan pemaknaan & $\begin{array}{c}\text { Nilai informatif } \\
\text { dalam merubah } \\
\text { pendapat }\end{array}$ \\
\hline \multirow{3}{*}{ Denotasi } & $\begin{array}{l}\text { BBM naik Rakyatnya } \\
\text { jadi pada miskin .. } \\
\text { BBM naik Rakyat gak } \\
\text { punya apa-apa .. }\end{array}$ & $\begin{array}{l}\text { Titik menunjukkan adanya } \\
\text { aspek penekanan informasi } \\
\text { pada masalah }\end{array}$ & $\begin{array}{l}\text { Bahan bakar minyak } \\
\text { adalah tulang } \\
\text { punggung ekonomi } \\
\text { rakyat }\end{array}$ \\
\hline & $\begin{array}{l}\text { Kita di suruh ngirit- } \\
\text { ngirit, DPR minta naik } \\
\text { gaji .. }\end{array}$ & $\begin{array}{l}\text { Tanda koma menunjukkan } \\
\text { adanya hegemoni, tanda titik } \\
\text { menunjukkan aspek } \\
\text { penekanan }\end{array}$ & $\begin{array}{l}\text { Adanya sikap para } \\
\text { pejabat yang } \\
\text { mementingkan diri } \\
\text { sendiri }\end{array}$ \\
\hline & $\begin{array}{l}\text { "BBM naik Kepanikan } \\
\text { di mana-mana ! panik } \\
\text { di POM-POM Bensin, } \\
\text { Panik orang menuntut } \\
\text { dana kompensasi .. }\end{array}$ & $\begin{array}{l}\text { Tanda kutip di awal } \\
\text { menunjukkan kekhasan } \\
\text { infomasi, tanda seru } \\
\text { menunjukkan adanya nilai } \\
\text { emosional, tanda titik dan } \\
\text { koma: aspek penekanan }\end{array}$ & $\begin{array}{l}\text { Pemerintah belum } \\
\text { mampu menangani } \\
\text { permasalahan Bahan } \\
\text { Bakar Minyak (BBM) } \\
\text { dengan tepat }\end{array}$ \\
\hline \multirow{2}{*}{ Konotasi } & $\begin{array}{l}\text { Generasi....Masa } \\
\text { Depan. Gak } \\
\text { Berpendidikan...Penya } \\
\text { kitan! }\end{array}$ & $\begin{array}{l}\text { Titik: menunjukkan } \\
\text { penekanan masalah, tanda } \\
\text { seru: ungkapan emosional, } \\
\text { penggunaan bahasa non } \\
\text { formal menunjukkan nilai } \\
\text { kedekatan pesan dengan } \\
\text { audien }\end{array}$ & $\begin{array}{l}\text { Pendidikan, kesehatan } \\
\text { dan kesejahteraan bagi } \\
\text { rakyat harus menjadi } \\
\text { prioritas utama } \\
\text { pemerintah }\end{array}$ \\
\hline & $\begin{array}{l}\text { Para Pejabat foya-foya } \\
\text {.. oya .. AHA ! } \\
\text { Kelebihan dananya } \\
\text { kemana? }\end{array}$ & $\begin{array}{l}\text { Titik: menunjukkan } \\
\text { penekanan masalah, tanda } \\
\text { tanya: bersikap kritis, dan } \\
\text { adanya bahasa non formal } \\
\text { dan tanda seru menujukkan } \\
\text { adanya nilai emosional } \\
\text { pesan terhadap audien }\end{array}$ & $\begin{array}{l}\text { Pejabat melaksanakan } \\
\text { tindak pidana korupsi } \\
\text { dengan penyelewengan } \\
\text { dana bantuan } \\
\text { kompensasi }\end{array}$ \\
\hline
\end{tabular}


Vol 1 No. 1, 2018, 97-130

DOI: https://doi.org/10.30596/persepsi.v1i1.2510

\begin{tabular}{|l|l|l|l|}
\hline & $\begin{array}{l}\text { Tambah noda Hitam } \\
\text { PERTAMINA .. oya } ! \\
\text { AHA }\end{array}$ & $\begin{array}{l}\text { Titik: menunjukkan } \\
\text { penekanan masalah, dan } \\
\text { adanya bahasa non formal } \\
\text { dan tanda seru menujukkan } \\
\text { adanya nilai emosional } \\
\text { pesan terhadap audien }\end{array}$ & $\begin{array}{l}\text { PERTAMINA sebagai } \\
\text { perusahaan BUMN } \\
\text { tidak pro kepada rakyat }\end{array}$ \\
\cline { 2 - 4 } & $\begin{array}{l}\text { Alur cerita yang } \\
\text { Kenunjukkan indikasi } \\
\text { kenyelewengan dana } \\
\text { bantuan, kejelasan cerita } \\
\text { dengan menggunakan latar } \\
\text { setting percakapan antara } \\
\text { Pak RT dengan Ahmad } \\
\text { Saleh. }\end{array}$ & $\begin{array}{l}\text { Aliran dana dari } \\
\text { pemerintah rentan } \\
\text { terhadap korupsi, baik } \\
\text { pejabat tinggi maupun } \\
\text { rendah }\end{array}$ \\
& & \\
&
\end{tabular}

Secara konotatif maupun denotatif dapat dilihat penggunaan bahasa, istilah dan pungtuasi yang khusus (istimewa) yang memberi makna kepada audien bahwa lirik lagu Kritis BBM memang dapat menggambarkan realitas sosial dampak dari kenaikan harga Bahan Bakar Minyak (BBM) terhadap rakyat miskin. Dengan demikian sifat informatif dari lirik lagu Kritis BBM mengandung tujuan untuk mengubah pendapat audiensnya baik secara sadar maupun tidak sadar.

\section{Mempengaruhi}

Sebagaimana yang telah diungkap peneliti, tanda dalam lirik lagu Kritis BBM karya Slank bahwa tujuan dari komunikasi massa melalui lirik lagu tersebut, Slank mencoba mempengaruhi audiennya agar kritis terhadap berbagai kebijakan pemerintah yang tidak pro kepada rakyat miskin. Hal ini dapat dilihat pada penggalan-penggalan kalimat dari rangkaian lirik lagu Kritis $B B M$ pada tabel berikut ini:

Tabel 4.4. Nilai Kritis dalam Kandungan Lirik Lagu Kritis BBM Perspektif Tujuan Komunikasi Bermuatan Mempengaruhi Audiens

\begin{tabular}{|c|c|c|c|}
\hline Analisa & Penggalan Lirik & Tanda & Nilai Kritis \\
\hline \multirow[b]{2}{*}{ Denotasi } & $\begin{array}{l}\text { Gak } \\
\text { BERPENDIDIKAN.... } \\
\text { PENYAKITAN! }\end{array}$ & $\begin{array}{l}\text { Penggunaan } \\
\text { bahasa non } \\
\text { formal "Gak" }\end{array}$ & $\begin{array}{l}\text { Sindiran dan sinis dalam menilai } \\
\text { kebijakan pemeritah }\end{array}$ \\
\hline & $\begin{array}{l}\text { Kita di suruh ngirit-ngirit, } \\
\text { DPR minta naik gaji .. }\end{array}$ & $\begin{array}{l}\text { Penggunaan } \\
\text { bahasa non } \\
\text { formal "ngirit- } \\
\text { ngirit" }\end{array}$ & $\begin{array}{l}\text { Hegemoni, sindiran terhadap } \\
\text { sikap pejabat legislatif }\end{array}$ \\
\hline \multirow{3}{*}{ Konotasi } & $\begin{array}{l}\text { Para Pejabat foya-foya .. } \\
\text { oya .. AHA ! } \\
\text { Tambah noda Hitam } \\
\text { PERTAMINA .. oya ! } \\
\text { AHA }\end{array}$ & $\begin{array}{l}\text { Penggunaan } \\
\text { istilah "AHA" } \\
\text { dan "oya" }\end{array}$ & $\begin{array}{l}\text { Justifikasi, sinis, stereotip negatif } \\
\text { dan berpikir kritis terhadap sikap } \\
\text { pejabat yang korupsi }\end{array}$ \\
\hline & $\begin{array}{l}\text { BBM naik hidup penuh } \\
\text { tanda tanya? }\end{array}$ & Tanda tanya & $\begin{array}{l}\text { Kritis dalam menyikapi faktor } \\
\text { penyebab kenaikan harga Bahan } \\
\text { Bakar Minyak (BBM) }\end{array}$ \\
\hline & $\begin{array}{l}\text { Kelebihan dananya } \\
\text { kemana? }\end{array}$ & Tanda tanya & $\begin{array}{l}\text { Kritis dalam menyikapi kebijakan } \\
\text { pemerintah dalam } \\
\text { mengalokasikan dana kompesasi }\end{array}$ \\
\hline
\end{tabular}


Berdasarkan tabel di atas, muatan-muatan dalam lirik lagu Kritis BBM karya Slank (signifier), mencoba mempengaruhi audiens (signifield) agar lebih memahami secara kritis terhadap realitas sosial kenaikan harga Bahan Bakar Minyak (BBM) memiliki dampak yang signifikan terhadap rakyat miskin. Selain itu juga dapat berpotensi mempengaruhi audien agar bersikap sinis dan menyindir terhadap kebijakan pemerintah, karena lirik lagu tersebut menggunakan bahasa non formal yang kasar termasuk penggunaan istilah yang berkonotasi pada pemaknaan stereotip negatif terhadap pemerintah.

3. Mengubah sikap dan perilaku

Melalui nilai informatif dan kandungan yang dapat mempengaruhi kognitif audiens dalam memaknai lirik lagu Kritis BBM pada penjelasan sebelumnya. Tingkat lanjutan dari informatif dan mempengaruhi audien tentunya lirik lagu Kritis $B B M$ memiliki tujuan untuk merubah sikap dan perilaku audien. Hal ini menyangkut aspek apektif pada tujuan komunikasi. Audien melalui lirik lagu ini digiring untuk memiliki sikap bertindak jika ada kejanggalan pada kebijakan pemerintah.

Sikap ini dapat berupa demonstrasi tolak kenaikan harga bahan bakar minyak, menuntut pemberdayaan rakyat yang lebih sejahtera dan lain sebagainya. Inilah yang menjadi tujuan dari alur dan latar setting Kisah Ahmad Saleh yang menuntut dana kompensasi kepada Pak RT. Namun sikap Pak RT berklise dengan menutupi keadaan dan kesalahan dalam nama dalam daftar penerima bantuan dana kompensasi. Maka tujuan dari kisah ini pada dasarnya adalah sebagai contoh tindakan yang tidak benar yang tidak patut ditiru oleh audiennya. Jadi lirik tersebut juga menekankan harus adanya perubahan sikap bagi semua elemen masyarakat, khususnya para pejabat dari high level management hingga low level management agar sadar bahwa perbuatan korupsi merupakan keburukan moral. Pesan moral kisah Ahmad Saleh dengan Pak RT dalam lirik lagu Kritis BBM yang tidak disampaikan secara langsung adalah bertujuan mengajak rakyat atau siapa saja dengan tegas menolak korupsi dan penyalahgunaan wewenang.

\section{Simpulan}

Adapun simpulan dari hasil penelitian ini adalah benar adanya konstruksi realitas sosial dampak kenaikan harga bahan bakar minyak dalam lirik lagu Kritis BBM karya Slank secara denotatif dan konotatif. Pesan-pesan yang muncul mengangkat tentang realitas pendidikan, kesehatan, dan kesejahteraan rakyat miskin. Kebenaran tersebut dibuktikan pada penggunaan bahasa, pemakaian istilah, pungtuasi dan rangkaian pesan komunikasi yang bersifat kritis terhadap kebijakan pemerintah. Untuk itu hasil penelitian menunjukkan denotasi dan konotasi mengandung konstruksi realitas sosial pada rangkaian lirik lagu Kritis BBM.

Bentuk dari konstruksi realitas sosial dampak kenaikan harga bahan bakar minyak dalam lirik Lagu Kritis BBM Karya Slank adalah realisme hipotesis yakni menggambarkan pesan konstruktif tentang regenerasi masa depan, masa depan pendidikan dan kesehatan, kurangnya kesejateraan pada rakyat miskin, hegemoni sosial pada rakyat miskin versus legislatif, taraf hidup rakyat miskin semakin susah, hegemoni sosial rakyat miskin dengan konsep hidup sederhana, rakyat menderita pejabat memperkaya diri, kebijakan pemerintah tidak transparan, tuntutan rakyat terhadap tranparansi pemerintah, citra buruk pertamina sebagai ladang korupsi, guncangan stabilitas sosial bagi rakyat miskin dan kecurangan alokasi bantuan dana kompensasi. Sebagaimana tujuan pesan komunikasi dalam lirik lagu Kritis BBM yakni mengubah pendapat terhadap realitas sosial, mempengaruhi audiens 
secara kognitif agar terjadi perubahan sosial yang mengarah pada perubahan sikap dan perilaku. Khususnya yang berkaitan dengan kebijakan pemerintah yang tidak pro kepada rakyat tentang dampak kenaikan harga bahan bakar minyak.

\section{Referensi}

Bakohumas, Sebab - Sebab Kenaikan Harga Bahan Bakar Minyak (BBM), (Wia Bakohumas, 4 July 2013), http://bakohumas. kominfo.go.id/news. php?id=1167.

Basrowi, Sukidin. (2002). Metode Penelitian Kualitatif Perspektif Mikro, Surabaya: Insan Cendekian.

Berger, Peter L. dan Thomas Luckmann. (1991). The Social Construction of Reality: A Treatise in the Sociology of Knowledge, England: Penguin Books Ltd.

Bertens, K. (1999). Sejarah Filsafat Yunani, Yogyakarta: Kanisius.

Bungin, Burhan. 2007. Metode Penelitian Kualitatif, Bandung: Rajawali Press.

. (2007). Sosiologi Komunikasi; Teori, Paradigma dan Diskursus Teknologi Komunikasi di Masyarakat, Jakarta : Kencana.

Danesi, Marcel. (2002). Understanding Media Semiotics, New York: Oxford University Press Inc.

(2004). Messages, Signs, and Meanings: A Basic Textbook in Semiotics and Communication 3rd edition, Toronto: Canadian Scholars' Press Inc.

2008. Dictionary of Media and Communications, New York: M.E. Sharpe, Inc.80 Business Park Drive, Armonk.

Echols, John M. \& Hassan Shadily. (2005). Kamus Inggris-Indonesia, Jakarta: PT. Gramedia Pustaka Utama.

Effendy, Onong Udjana. (1994). Dinamika Komunikasi, Bandung: PT. Remaja Rosdakarya.

(1997). Ilmu Komunikasi Teori dan Praktek, Bandung: PT. Remaja Rosdakarya.

Firmansyah, Fahmi. Skripsi. (2011). Dari Cikini Stones Complex Hingga Slank: Sebuah Catatan Perjalanan Slank (1983-1996), www.lontar.ui.ac.id, Fakultas IImu Pengetahuan Budaya Universitas Indonesia.

Fiske, John. (1990). Introduction to Communication Studies Second Edition, London: Routledge.

Frith, Simon and Andrew Goodwin (ed), (2005). On Record Rock, Pop, And The Written Word, New York: Pantheon Books, a division of Random House, Inc,.

Gusman, Egie. Soal Lagu Kritik Pemerintah, Iwan Fals: Saya Sudah Dol!, (Okezone ,2014), http://musik.okezone.com/ read/2013/06/26/389/827721/ soal-lagu-kritikpemerintah- iwan-fals-saya-sudah-dol.

Hartono, Djoko Setyo. (2011). Dampak Kenaikan Harga BBM di Pasar Dunia Tantangan bagi Perekonomian Indonesia. Jurnal Value Added, Vol. 7, No. 2, Maret 2011 Agustus 2011, 23-30. http://jurnal.unimus.ac.id/

Keraf, Gorys, 1977, Komposisi Sebuah Pengantar Kepada Kemahiran Bahasa, Flores: Nusa Indah

Kompas Online, Berita Nasional, DPR Akan Gugat Slank, Senin, 7 April 2008 http:// nasional.kompas.com/read/2008/04/07/16244874/dpr. akan.gugat. slank.

Kriyantono, Rachmat. 2003. Teknik Praktis Riset Komunikasi: Disertai Contoh Praktis Riset Media, Public Relations, Advertising, Komunikasi Organisasi, Komunikasi Pemasaran, Jakarta: Kencana. 
Ma'arif, Syamsul. (2013). Perubahan Kebijakan di Sektor Migas Pasca Rezim Orde Baru. Jurnal Sawala, Vol. 2 No. 2, 1-2

Mattern, Mark. (1998). Acting in Concert: Music, Community, and Political Action, London: Rutgers University Press.

Moleong, Lexy J. (2010). Metodologi Penelitian Kualitatif, Bandung: PT. Remaja Rosdakarya.

Munawar, Dungtji. (2013), Memahami Pengertian dan Kebijakan Subsidi dalam APBN, www.bppk.depkeu.go.id.

Nawawi, Hadari. (2007). Metode Penelitian Bidang Sosial, Yogyakarta: Gajah Mada University Press.

Nota Keuangan dan Rancangan Anggaran Pendapatan dan Belanja Negara Tahun Anggaran 2014, www.anggaran.depkeu.go.id

Nugroho, Panji Suryo. Tesis. (2008). Membongkar Mitos Musik Pop Religi Dalam Mitologi Budaya Massa Islam Di Indonesia: Semiotika Sampul Album Pop Religi Ungu. www.library.walisongo.ac.id, Pascasarjana Konsentrasi Pemikiran Etika Islam/Tasawuf, IAIN Walisongo Semarang.

Nurahim, Skripsi. (2009). Kritik dan Realitas Sosial dalam Musik: Suatu Studi atas Lirik Lagu Slank. www.digilib.uin-suka.ac.id. UIN Sunan Kalijaga Yogyakarta, Fakultas Ilmu Sosial dan Humaniora, Jurusan Studi Sosiologi.

Ritzer, George. (2010). Sociological Theory, Eighth Edition, New York: McGraw-Hill Companies, Inc.

Rolnicki, Tom E. Dkk. (2008). Pengantar Dasar Jurnalisme Scholastics Journalism, diterjemahkan Tri Wibowo, Jakarta: Kencana.

Ross, Ron \& Susan Carson Cormier, (2010). Handbook for Citizen, Denver, Colorado: National Association of Citizen Journalists, www.NACJ.us

Sakiman, Siti Ainum. Tesis. (2012). Resistensi Melalui Musik Populer Kajian Konstruksi Budaya Dalam Album "Dari Rakyat Untuk Rakyat" dan Teks-teks Lagunya Sebagai Medium Resistensi. www.lontar.ui.ac.id, Pascasarjana FISIP UI Jakarta, Departemen Ilmu Komunikasi, Fakultas Ilmu Sosial dan Ilmu Politik Universitas Indonesia.

Saussure, Ferdinand de. (1983). Course in General Linguistics, London: Duckworth.

Sobur, Alex. (2004). Analisis Teks Media Suatu Pengantar untuk Analisis Wacana, Analisis Semiotik, dan Analisis Framing, Bandung: PT. Remaja Rodakarya.

Storey, John. (1996). Cultural Studies and The Study of Popular Culture: Theories and Methods. Athens: Edinburgh University Press, Edinburgh \& The University Georgia Press.

Suparno. (1997). Filsafat Konstruktivisme dalam Pendidikan, Yogyakarta: Kanisius.

Susetiawan, Harmoni. (1997). Stabilitas Politik dan Krtik Sosial, dalam Kritik Sosial dalam Wacana Pembangunan, Yogyakarta: UII Press.

Tim Penyusun Pusat Bahasa. (2008). Kamus Bahasa Indonesia, Jakarta: Balai Pustaka. 